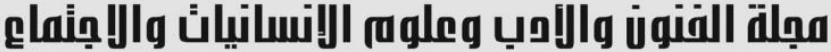

Journal of Arts, Literature, Humanities and Social Sciences www.jalhss.com

\section{متطلبات تطوير الممارسات القيادية الاعمة للتعلم المهني بمدارس التعليم العام الماع}

مبارك بن عبدالله مبارك الدوسري باحث دكتور اهن

كلية التربية ـ جامعة الملك سعود ـ الرياض ـ ـ المملكة العربية السعودية البريد الإليكتروني: m.dossary2015@gmail.com

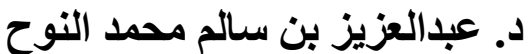

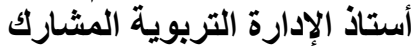
كلية التربية ـ جامعة الملك سعود ـ الرياض الئرئ ـ المملكة العربية السعودية

الملخص

هدفت الدر اسة إلى تحديد المتطلبات (التنظيمية، والمادية، و البشرية) اللازمة لتطوير الممارسات القيادية الداعمة للتعلم المهني بمدارس التعليم العام. استخدمت الدر اسة المنهج الوصفي، والمقابلة أداة لها. وتكونت عينة الدراسة من (9) قادة مدارس و(5) مشرفي قيادة مدرسية بالإدارة العامة للتعليم بمنطقة الرياض، و(6) مشرفي تطوير مهني بالمركز الوطني للتطوير المهني التعليمي بوزارة التعليم. وتوصلت الدر اسة إلى النتائج التالية: 1. المتطلبات التنظيمية اللازمة لتطوير الممارسات القيادية الداعمة للتعلم المهني كان أبرزها: نشر ثقافة التعلم المهني، وضع السياسات المنظمة للتعلم المهني بمدارس التعليم العام، منح الصلاحيات الممكنة لقائد المدرسة في دعم التعلم المهني. 2. المتطلبات المادية اللازمة لتطوير الممارسات القيادية الداعمة للتعلم المهني كان أبرزها: بناء قاعدة بيانات متكاملة عن مجتمع المدرسة، وضع حوافز مادية ومعنوية تشجع التعلم المهني، توفر القاعة و التجهيزات التقنية اللازمة للتعلم المهني. 3. المتطلبات البشرية الكازمة لتطوير الممارسات القيادية الداعمة للتعلم المهني كان أبرزها: تأهيل قائد المدرسة على قيادة التعلم المهني في المدرسة، بناء فريق التعلم المهني، توفر الكوادر الإدارية المساندة لقائد المدرسة. 


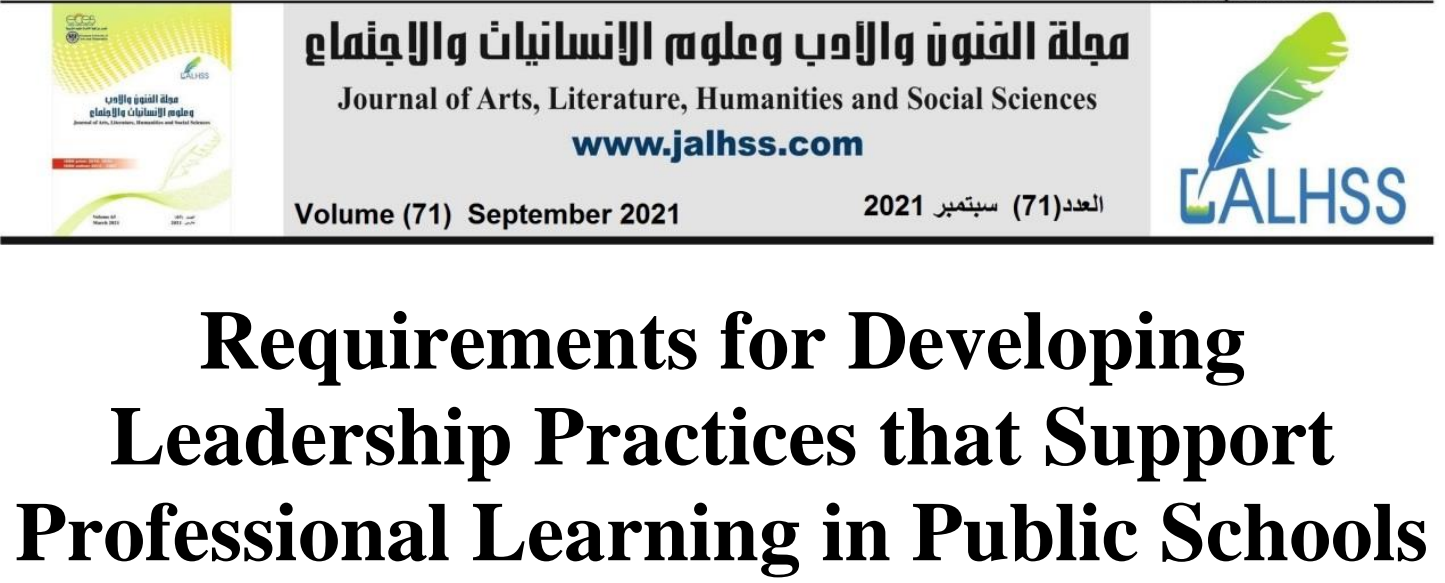

\author{
Mubarak Abdullah M. AL Dossary \\ Doctoral Candidate \\ College of Education- King Saud University- Riyadh- Saudi Arabia \\ Email: m.dossary2015@gmail.com
}

Dr. Abdulaziz Salem M. AL Nooh

Associate Professor, Educational Administration

College of Education- King Saud University- Riyadh- Saudi Arabia

\begin{abstract}
The purpose of this study is to identify (organizational, material, human) requirements for developing leadership practices that support professional learning in public schools. A descriptive approach was used to achieve these goals, using a semistructured interviews with (9) school leaders, (5) school leadership supervisors, and (6) professional development supervisors. Findings of the study:

1. The organizational requirements for developing leadership practices that support professional learning: advocating a culture of professional learning, establishing polices that organize professional learning in public schools, providing the school leader with authorities that empowers him to support professional learning.

2. The material requirements for developing leadership practices that support professional learning: building a complete data base for the school community, setting rewards to motivate professional learning, providing a meeting room prepared with technical equipment for professional learning.

3. The human requirements for developing leadership practices that support professional learning: qualifying school leaders to lead professional learning, building a professional learning team, providing supportive staff for the school leader.
\end{abstract}

Keywords: Leadership Practices, Professional Learning, School Leader, School Leadership. 


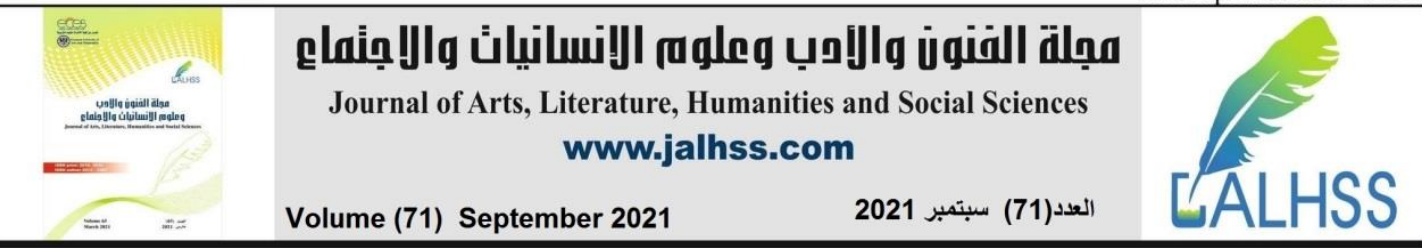

المقدمة

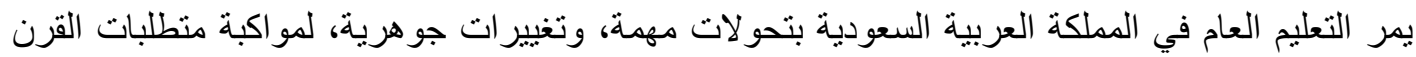

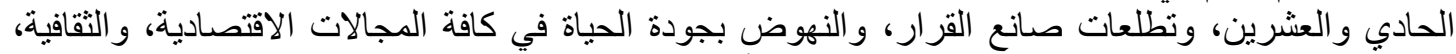

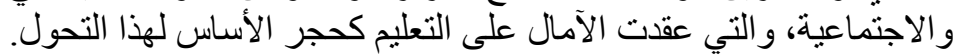

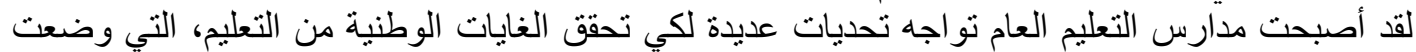

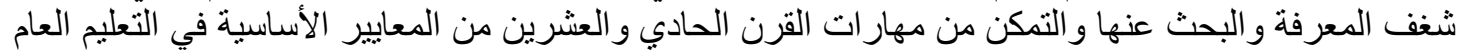

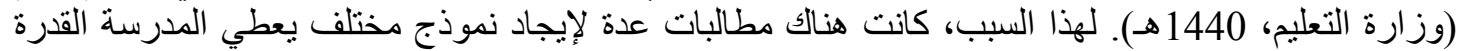

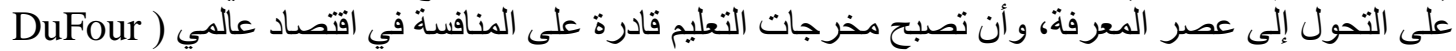
.\& Eaker, 1998 لذلك تعد القيادة المدرسية مرتكز اً رئيساً لتحول المدرسة إلى مفهوم مجتمع المدرسة المتعلمة، من خلال رؤية

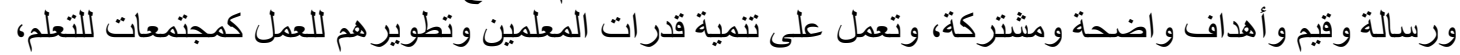

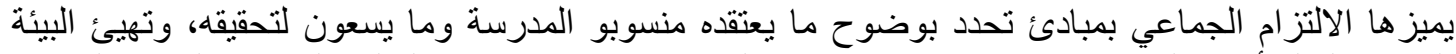

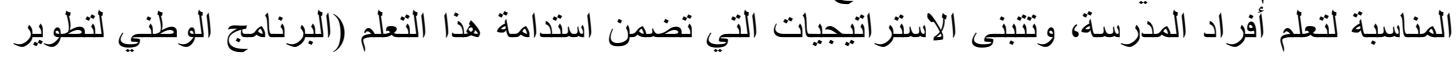

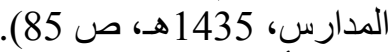

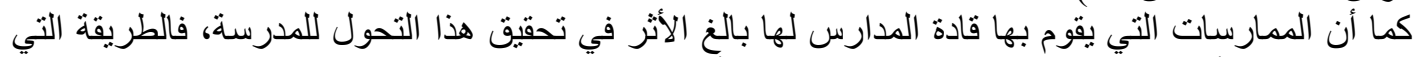

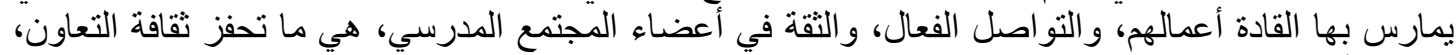
وتظهر أفضل ما لدى المعلمين من قدرات، وتدفع بهم نحو التغيير والتعلم باستمر ار، وتنمي التهاء الثعور بالانتماء

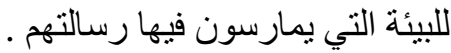

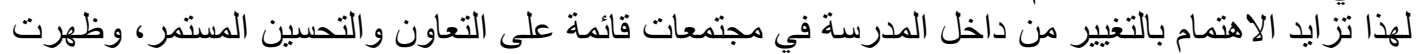

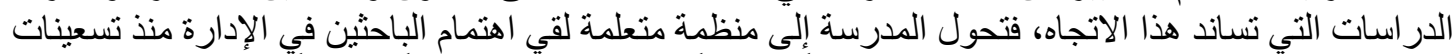

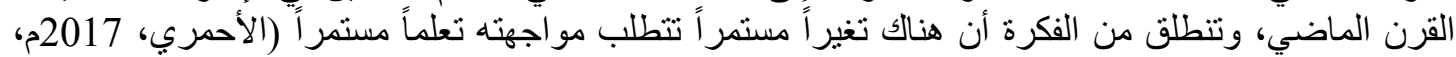

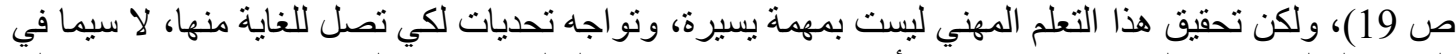

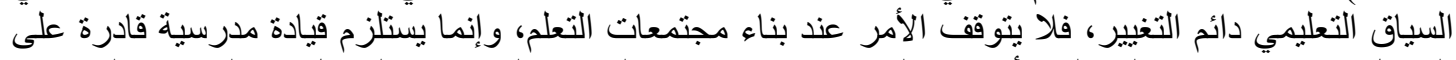

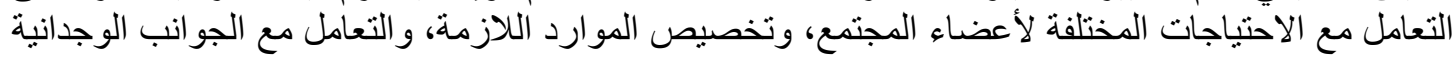

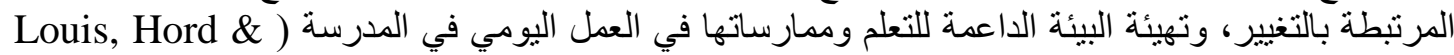

.(Frank, 2017, pp. 26-27 لأجل ذلك جاءت هذه الدراسة لتلقي بالضوء على على المنطلبات التي يحتاج إليها قادة المدارس في دعم التعلم

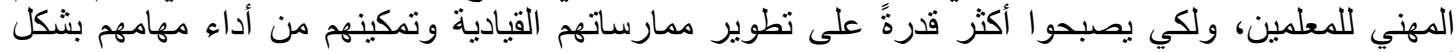

\section{مشكلة الاراسة}

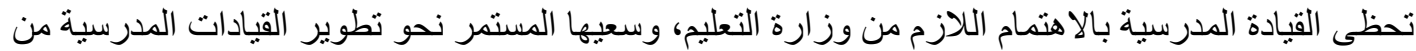

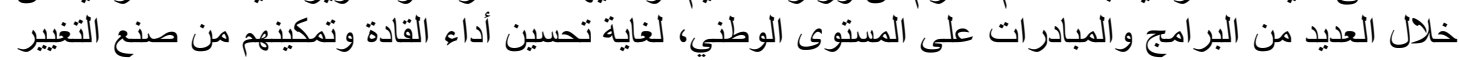

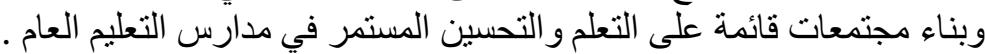

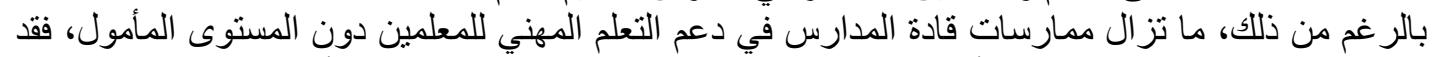

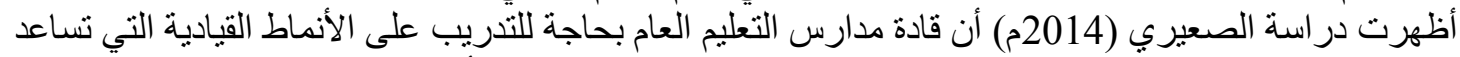

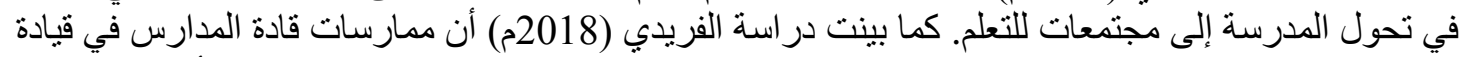

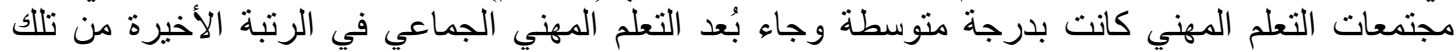

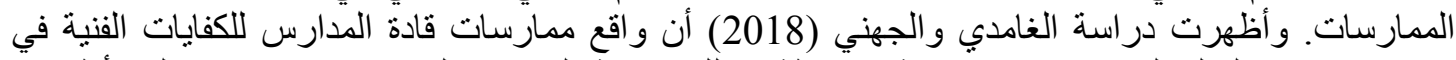

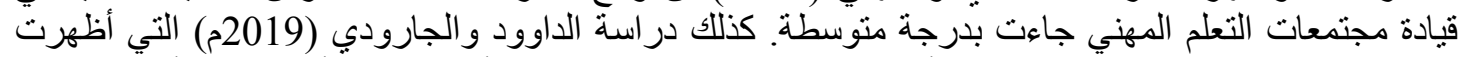

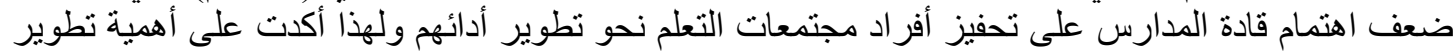
ممارسات القادة من خلال تدريبه على على الأنماط القيادية المعاصرة. 


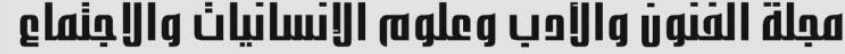

Journal of Arts, Literature, Humanities and Social Sciences www.jalhss.com

وفي ظل المطالبات المتز ايدة بتحسين أداء المدارس ومخرجاتها التعليمية، يجد قائد المدرسة في مواجهة

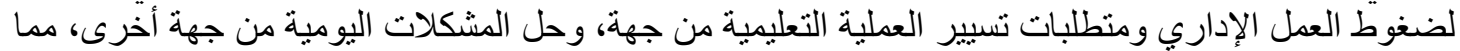

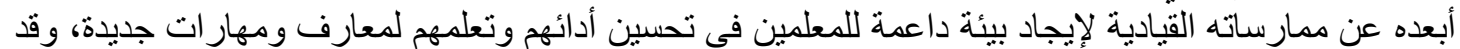

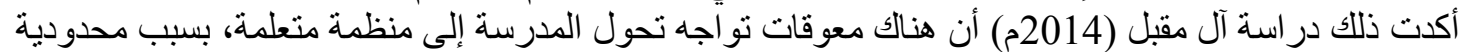

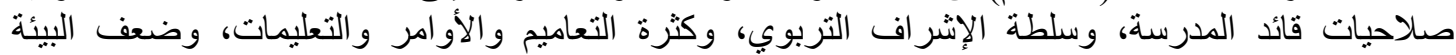

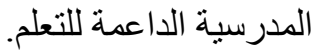

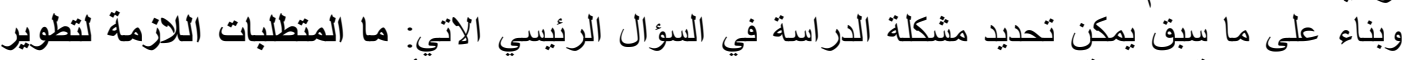

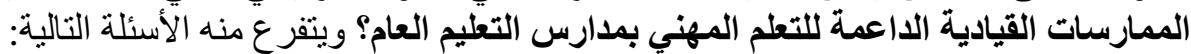

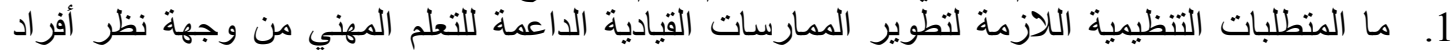

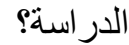

2. ما المتطلبات المادية اللازمة لتطوير الممارسات القيادية الداعمة للتعلم المهني من وجهة نظر أفراد

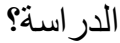

3. ما المنطلبات البشرية اللازمة لتطوير الممارسات القيادية الداعمة للتعلم المهني من وجهة نظر أفراد

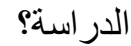

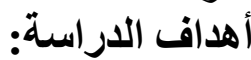
سعت الدر اسة إلى تحقيق الأهداف التالية: 1. تحديد المتطلبات التنظيمية اللازمة لتطوير الممارسات القيادية الداعمة للتعلم المهني بمدارس التعليم العام.

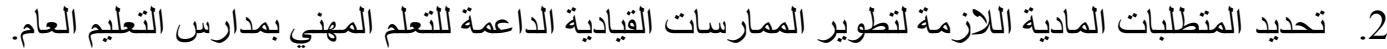
3. تحديد المتطلبات البشرية اللازمة لتطوير الممارسات القيادية الداعمة للتعلم المهني بمدارس التعلية التعليم العام.

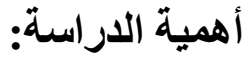

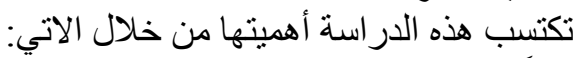

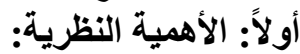
- ـ التأكيد على أهمية الممارسات القيادية التي يقوم بها قائد المدرسة و أثنرها في جانب تحسين أداء المعلمين

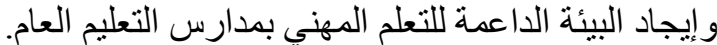

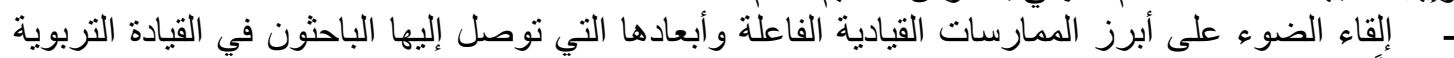

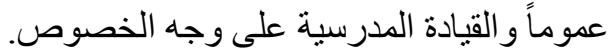

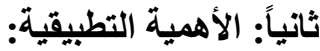

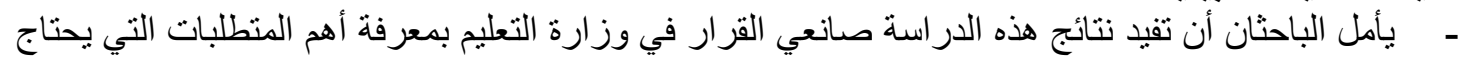

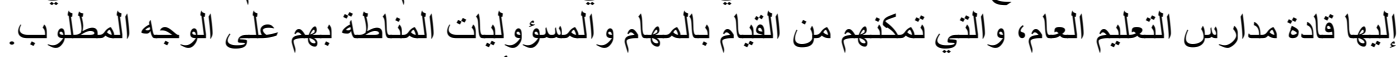

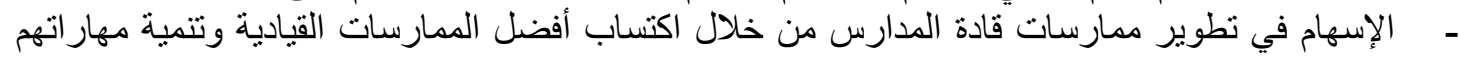
على قيادة التعليم و التعلم بمدارس التعليم التعار العام.

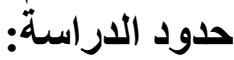
الحدود الموضوعية: اقتصرت هذه الدراسة على تحديد المنطلبات (التنظيمية، المادية، البشرية) اللازمة لتطوير

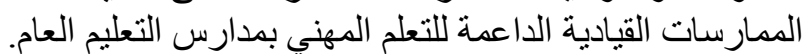

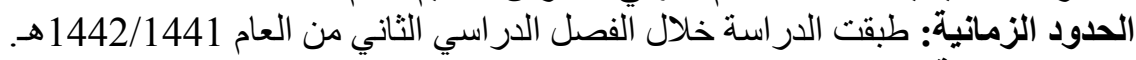

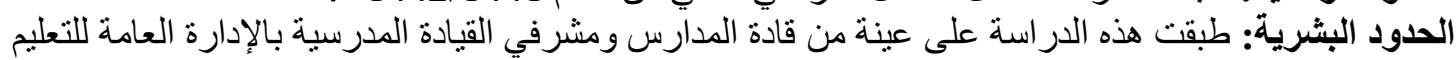

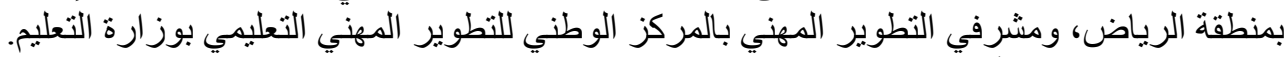

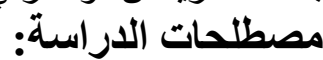

الممارسات القيادية (Leadership Practices)

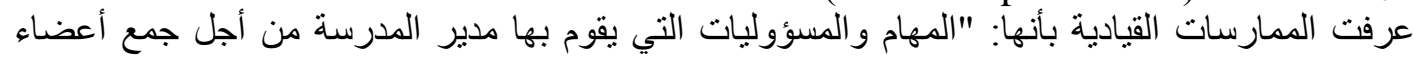

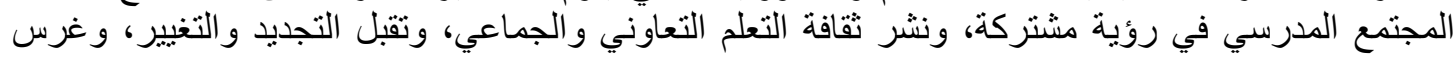

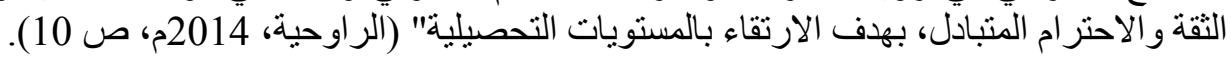




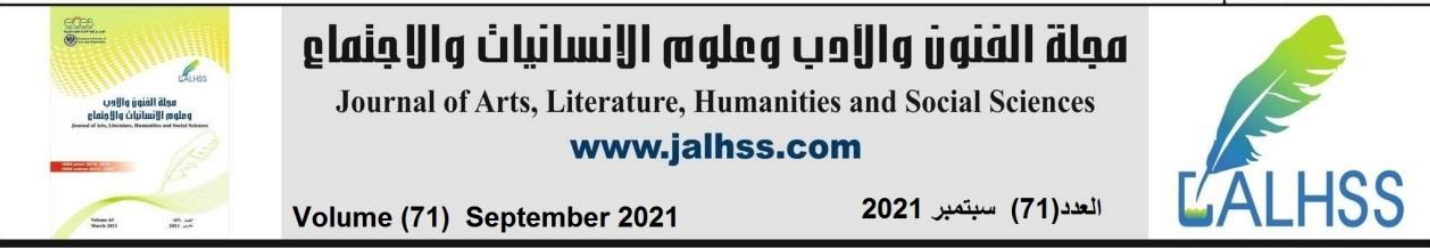

ويمكن تعريفها إجرائياً بأنها: الجهود التي يقوم به قائد المدرسة لأجل بناء رؤية ورسالة وقيم مشتركة، وبيئة

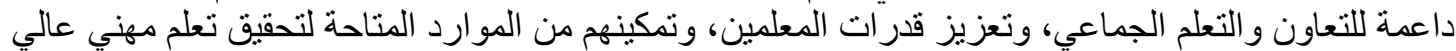

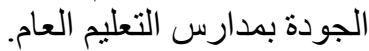

التعلم المهني (Professional Learning)

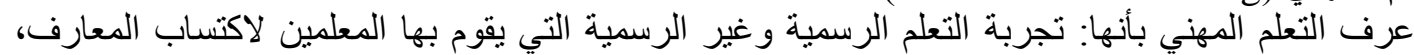

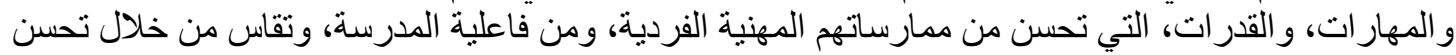

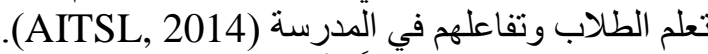

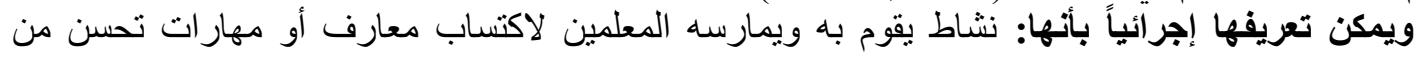

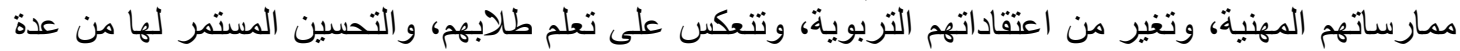
مصادر أساسها مجتمعات التعلم بمدارس التعليم العام.

\section{الإطار النظري والار اسات السابقة

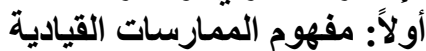

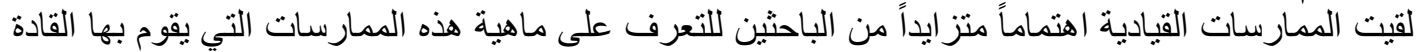

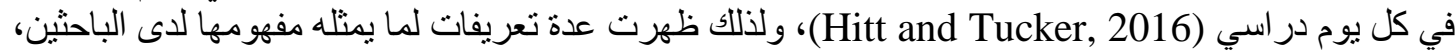

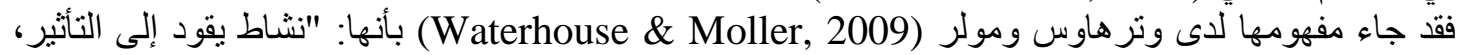

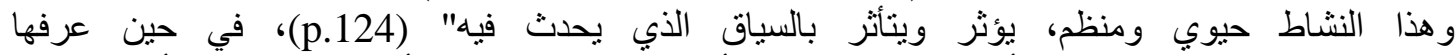

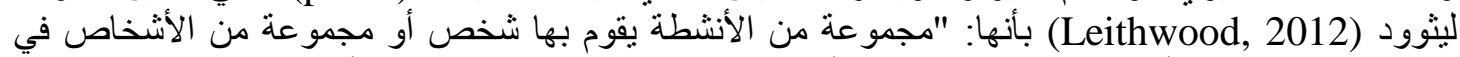

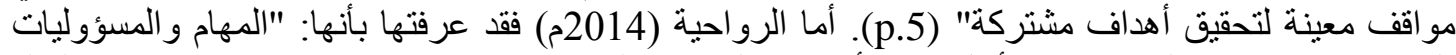

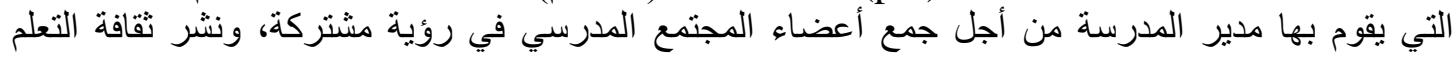

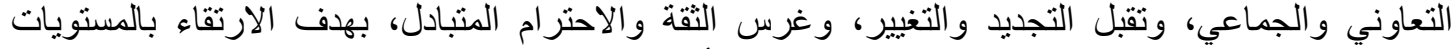

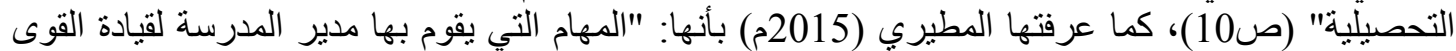

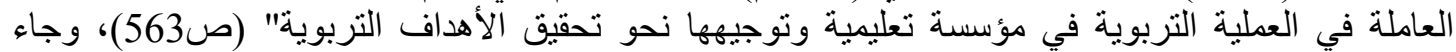

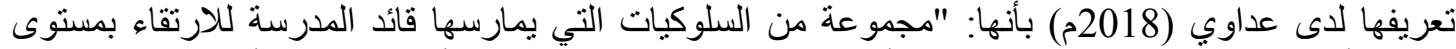

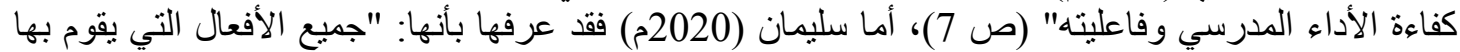

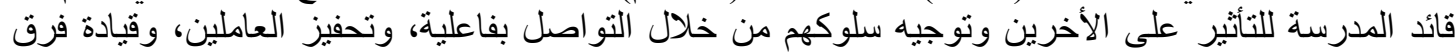

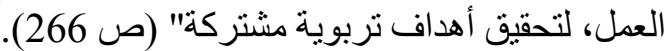

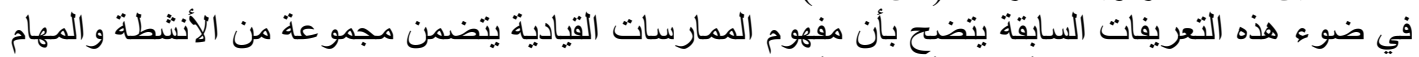

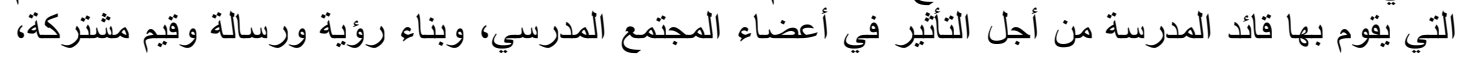

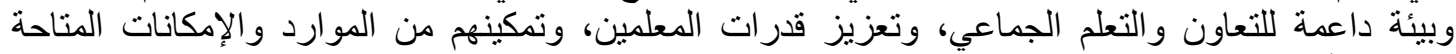

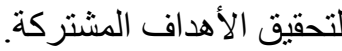
ثنانياً: خصائص الألمافرسات القيادية الفاعلة

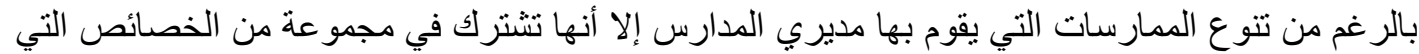

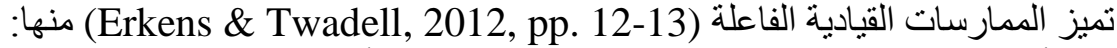
1. أنها تطبق لتدعم التغيير؛ تتطلب الممارسات القيادية أفكار مقصودة بغاية التغيير من الثقافة، و إعادة التنظيه،

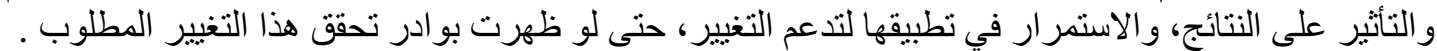

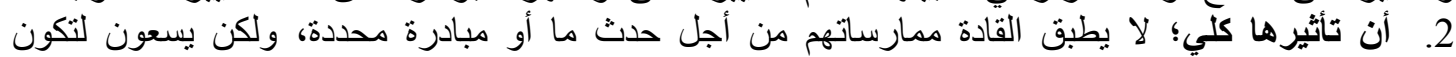

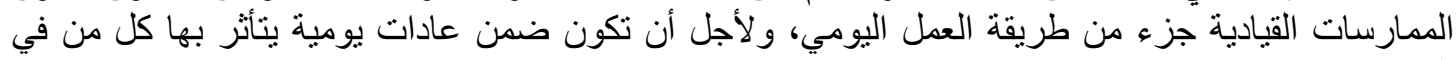
المدرسة.

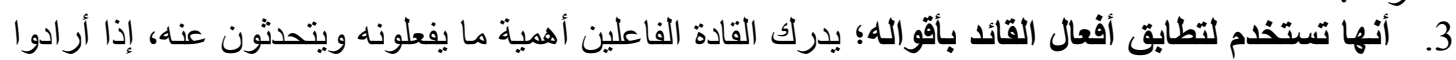

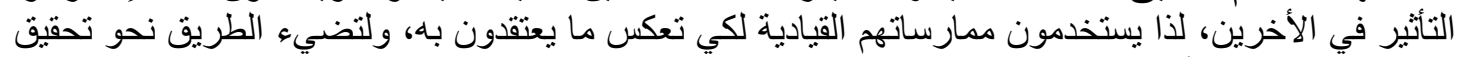
رؤية ورسالة وقيم و أهداف المدرسة، كما يجب على الإنى القادة تبني المعتقدات وتنتجيع العادات التي هم على استعداد لأن يصبحو ا قدوة بها أمام الأخرين . 


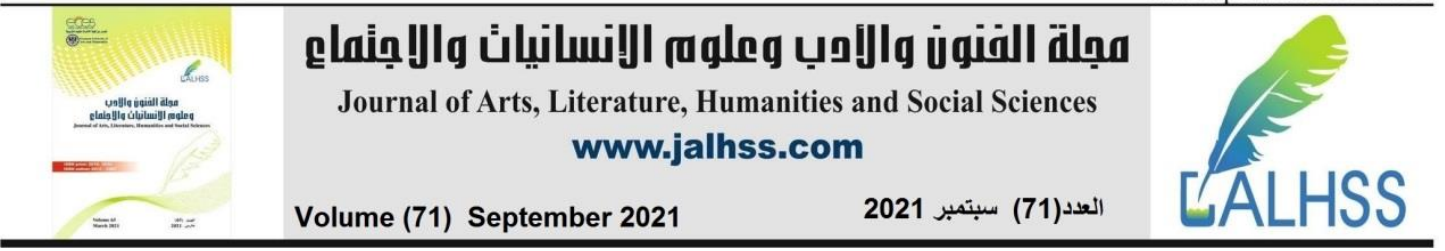

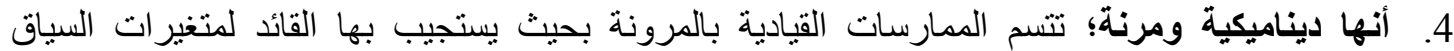

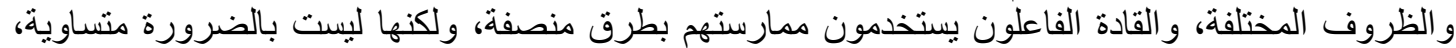

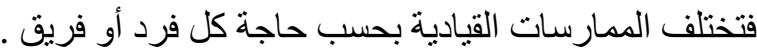

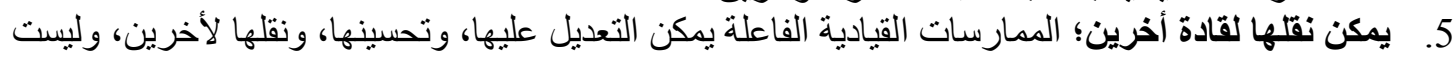

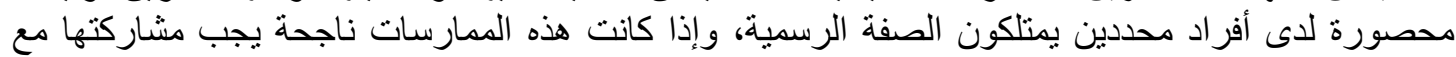
الجميع لاكتسابها، مما يمكن القائد من تطوير القيادة لدى الأخرين.

ثالثاً: أبعاد الممارسات القيادية الفاعلة

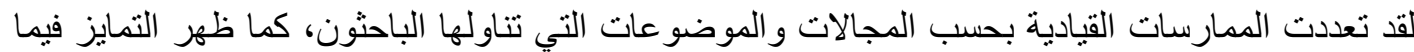

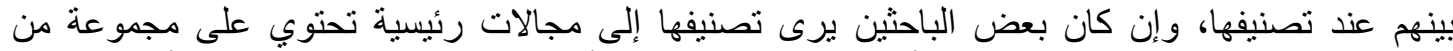

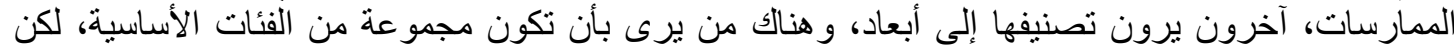

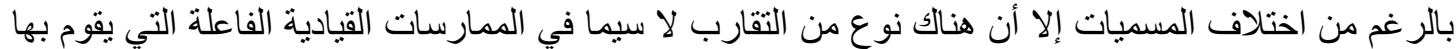

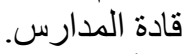
أجرى كوزوس وبوسنر دراسة في 1982م، وامتدت أكثر من ثلاثة عقود، للبحث عن الممارسات القيادية

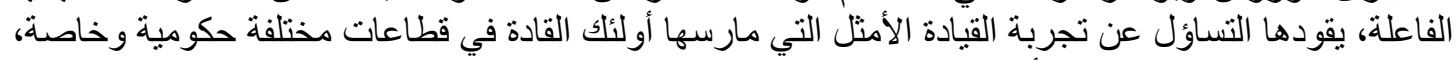

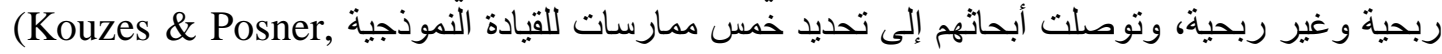
2012, pp.15-24)

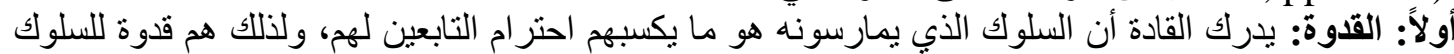

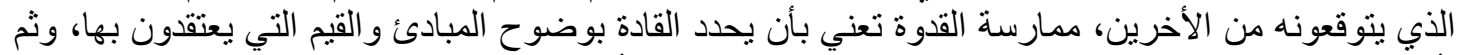

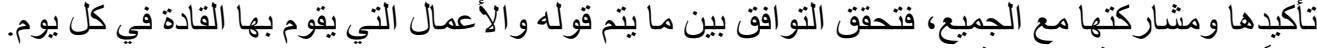

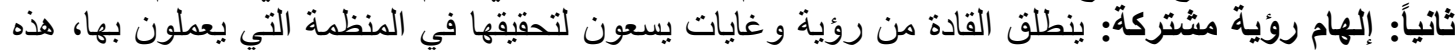

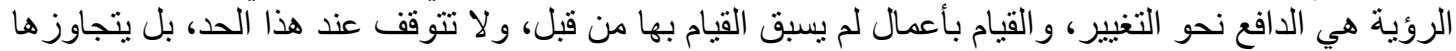

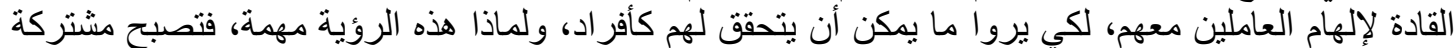

تيسعى الجميع لتحقيها.

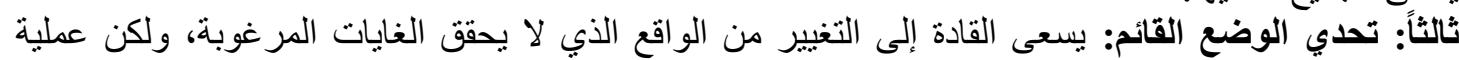

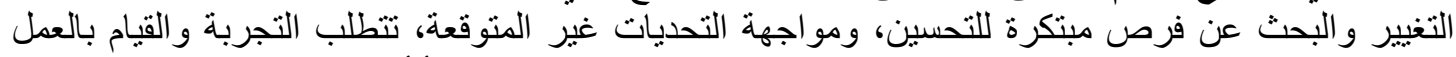

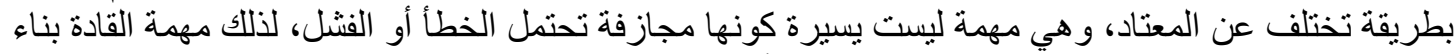

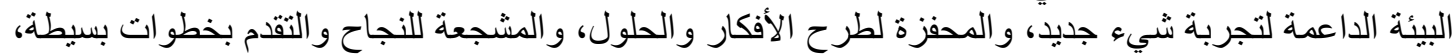

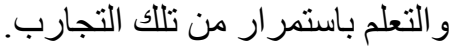
رابعاً: تمكين الأخرين: يعي القادة بأنه لا تتحقق الأهداف المشتركة إلا من خلال تمكين الأخرين، ومهما كانت

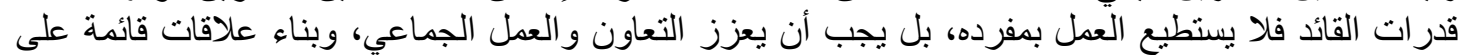

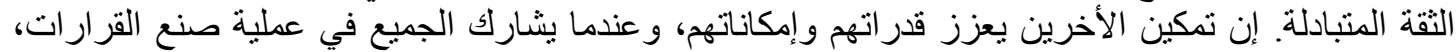

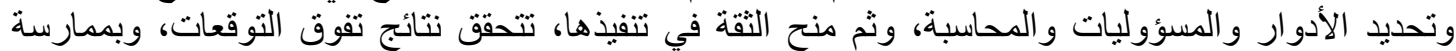

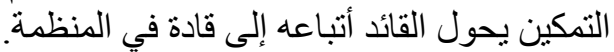

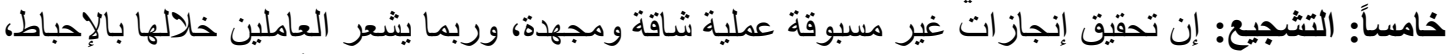

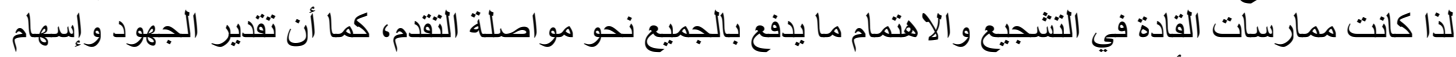

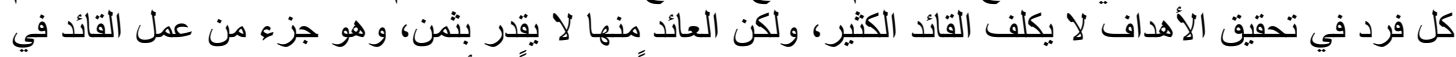

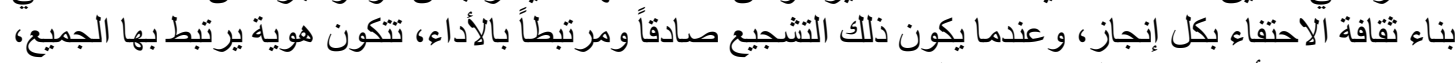

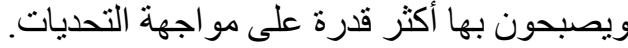

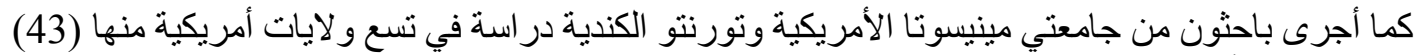

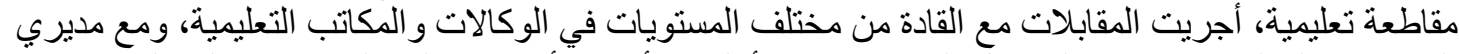

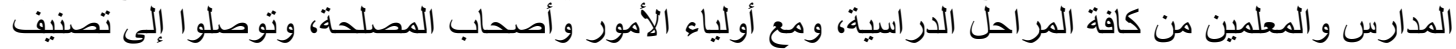

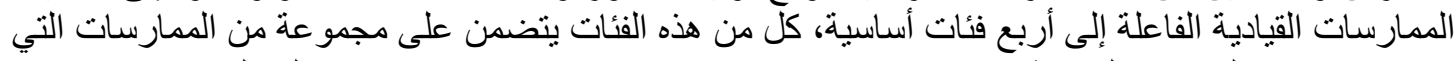

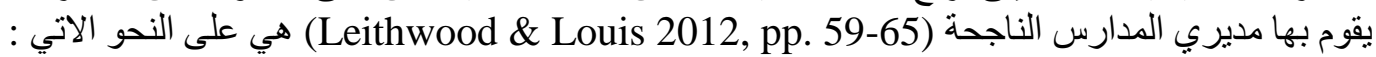




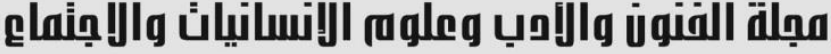

Journal of Arts, Literature, Humanities and Social Sciences www.jalhss.com

\section{أولاً: تحديد الوجهة}

تركز ممارسات هذه الفئة على توجيه الجهود نحو الغايات والأهداف التي تسعى المدرسة إلى تحقيقها، وتتضمن

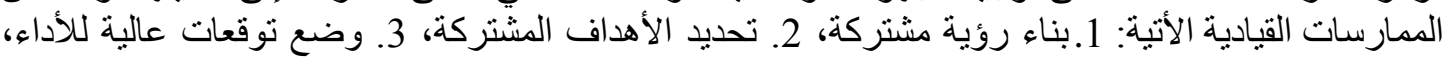

4. التو اصل بفاعلية عن هذه الوجهة.

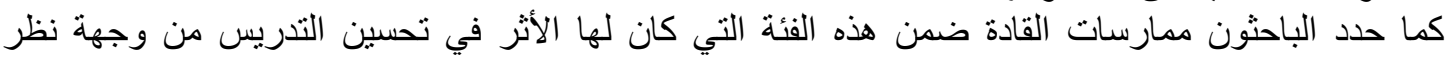

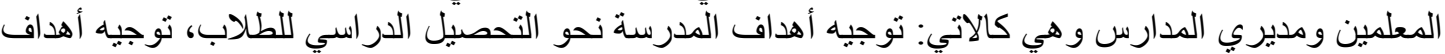

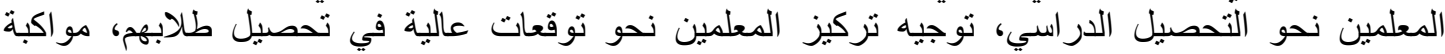

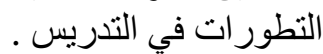

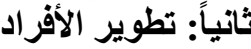

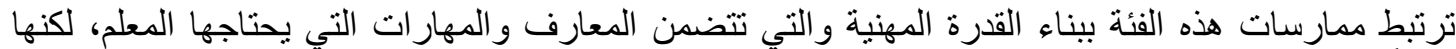

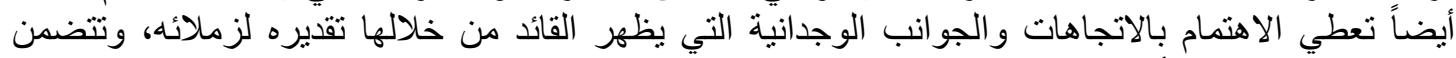

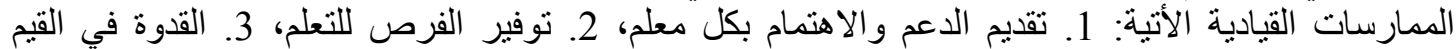

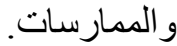
أما ممارسات القادة في هذه الفئة التي كان لها الأثر في تحسين التدريس من وجهة نظر المعلمين التهين ومديري

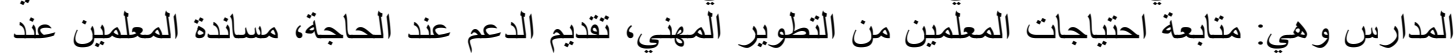

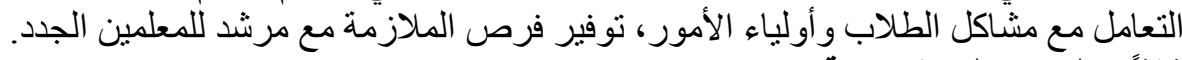

ثالثاً: تطوير تنظيم المدرسة

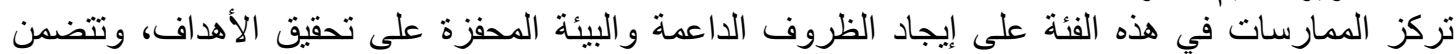

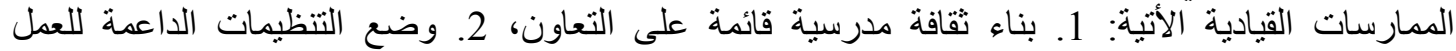

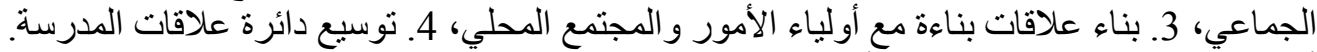

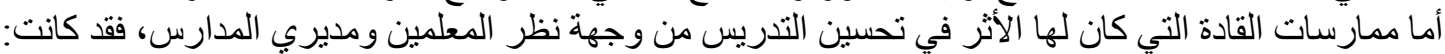
تيسير فرص التعاون بين المعلمين.

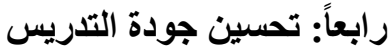

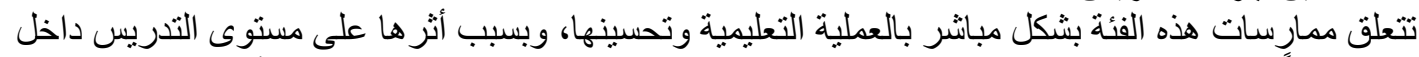

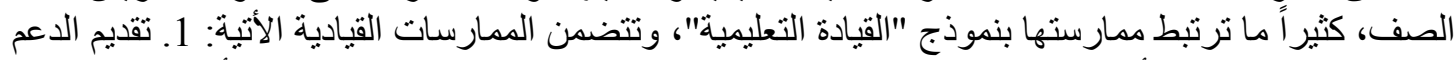

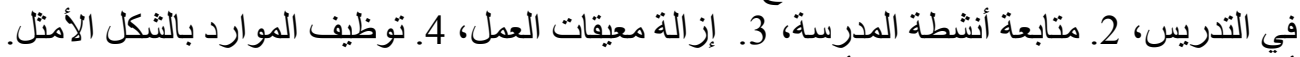

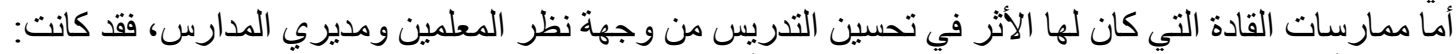

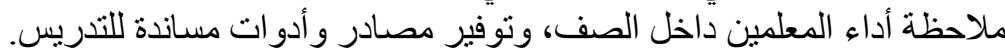
وفي التقرير الذي قدمته مؤسسة والاس (The Wallace Foundation) التي تدعم الدراسير التات في القيادة

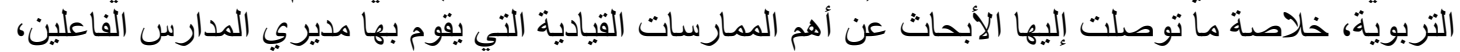

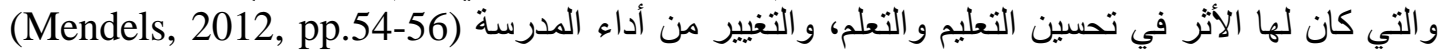

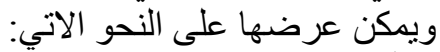

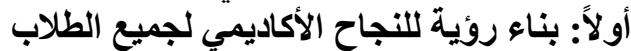

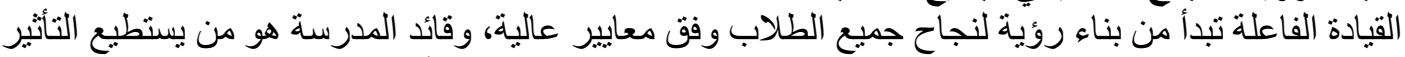

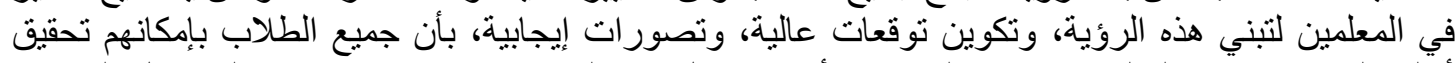

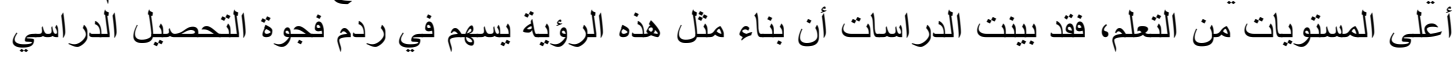

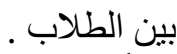

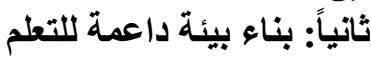

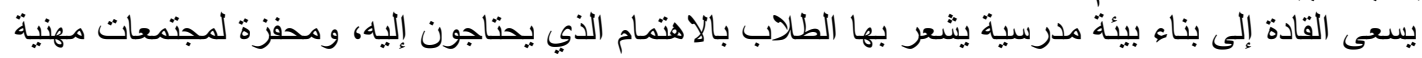

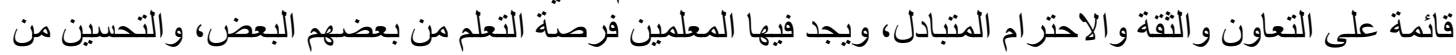
ممارستهم، و المشاركة في حل المشكلات . 


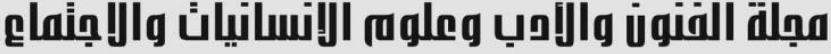

Journal of Arts, Literature, Humanities and Social Sciences www.jalhss.com

Volume (71) September 2021

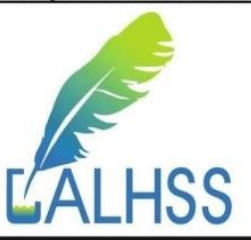

أعدرك القادة بأنه لا يمكن تحقيق الأهداف لوحدهم، ولذلك يسعون لتوظيف الخبر ات و المهار ات التي يمتلكها

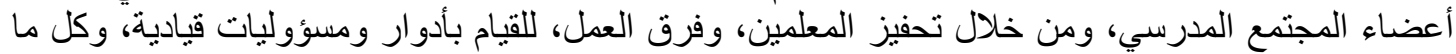

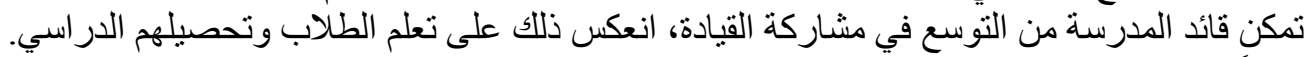

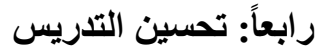

يهتم قادة المدارس الفاعلين بجودة التدريس، ويسعون إلى تبني الاستراتيجيات وطرق التهرئ التدريس التي أظهرت

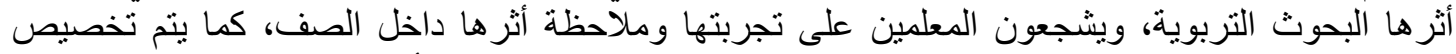
الموارد و الوقت اللازم ليتمكن المعلمين من التعلم الجماعي، بالإضافة إلى دعم أنشطة التطوير المهني التهني الموجهة لتحسبن التدريس.

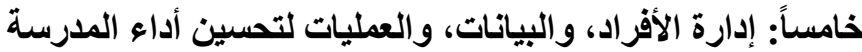

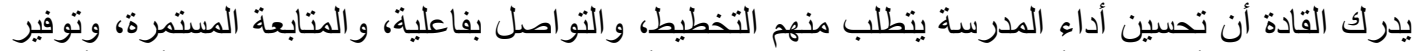

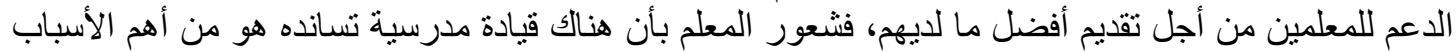

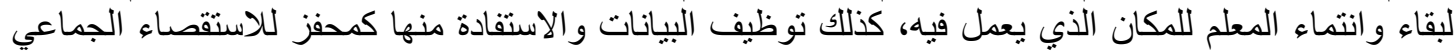

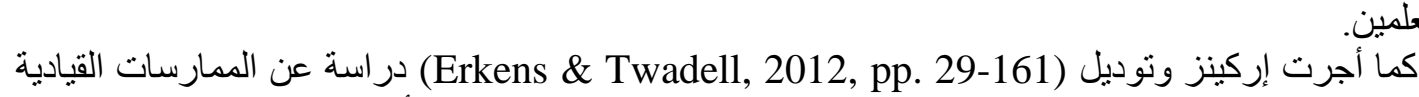

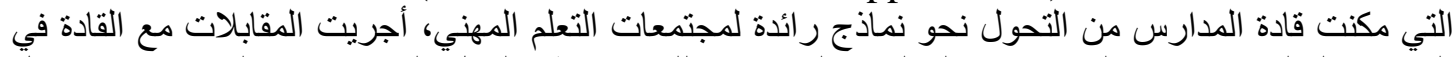

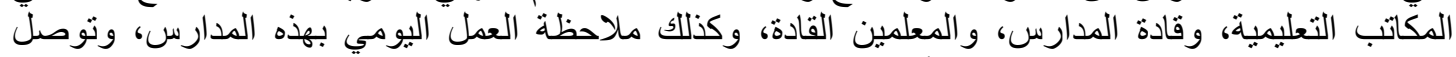

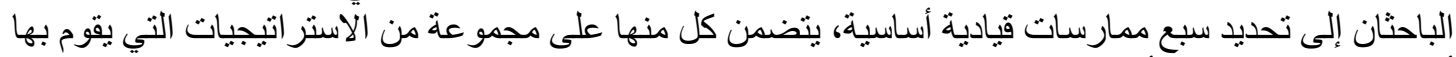

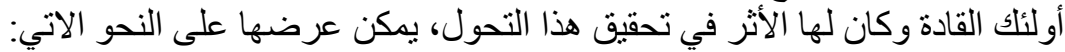

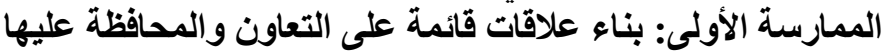

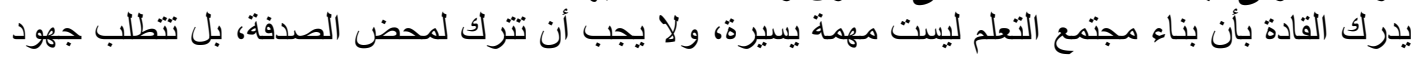

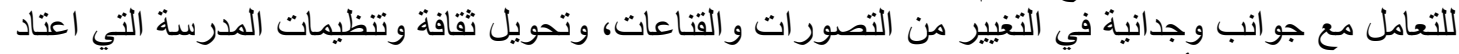

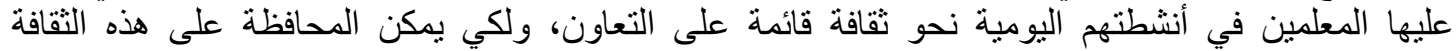

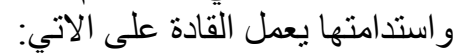

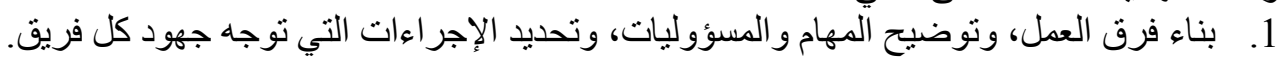

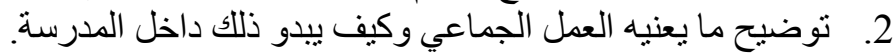

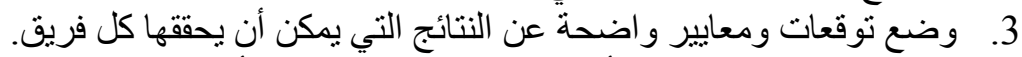
4. ت تمكين الفريق من اختيار الأساليب المناسبة في تحقيق الأهداف النئ.

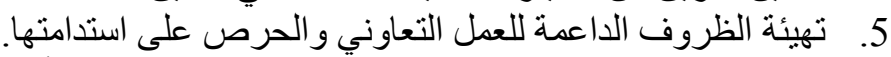

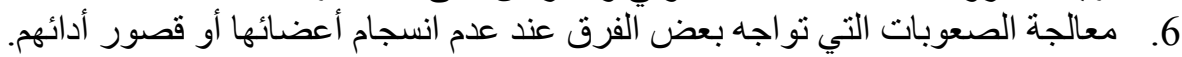

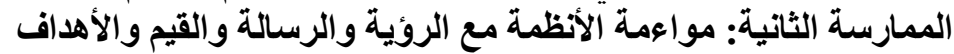

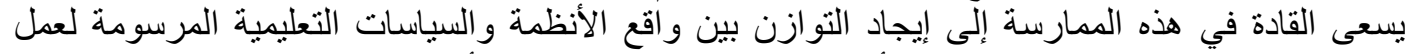

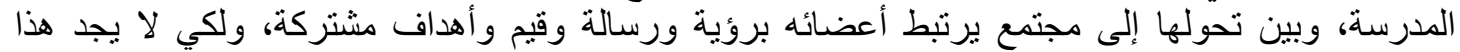

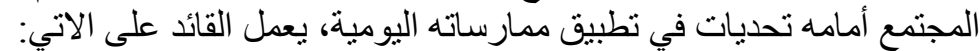

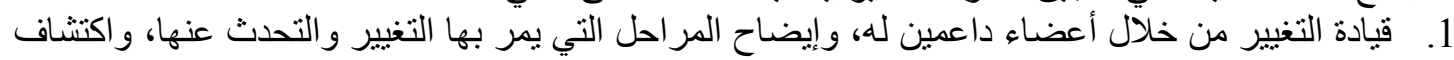
المعيقات و إز احتها، و إعطاء هذه العملية الوقت اعند الكافي لإتمامها.

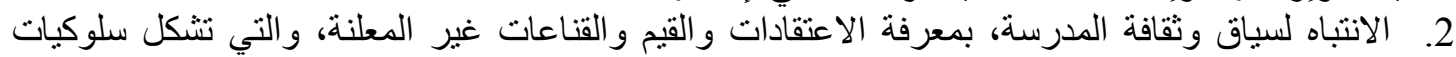

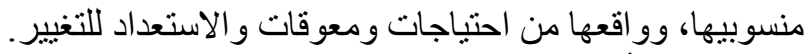
3. ت تحليل الأنظمة قبل مو اعمنها.

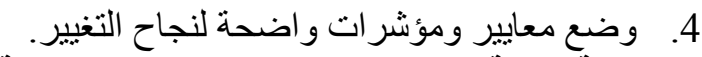
الممارسة الثالثة: تسهيل تحمل المسؤوليات المشتركة النيرة

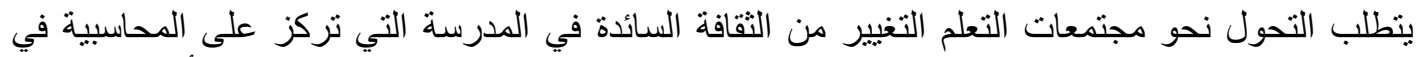

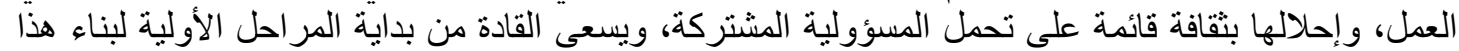

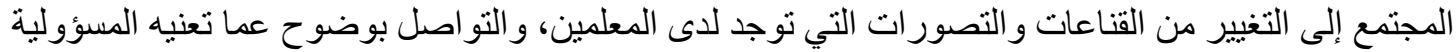
المشتركة، ولكي ينم هذا التغيير يعمل القادة على الاتي: 


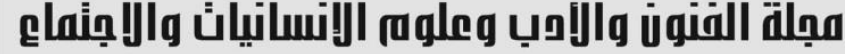

Journal of Arts, Literature, Humanities and Social Sciences www.jalhss.com

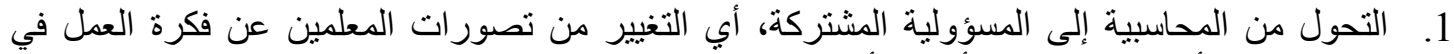

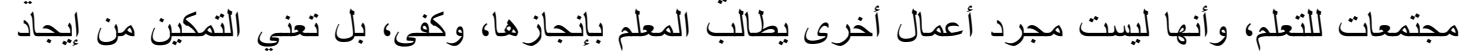

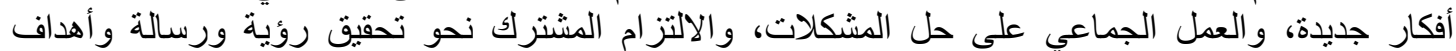
المدرسة. 2. بناء رو ابط قائمة على الثقة المتبادلة، لأن هناك علاقة مباثرة بين نجاح القائد في بناء ثقافة مدرسية قائمة

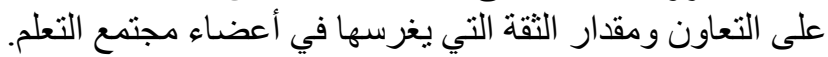

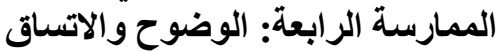

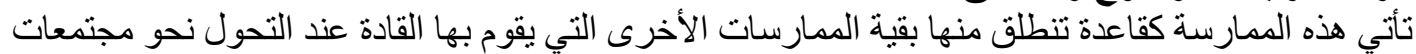

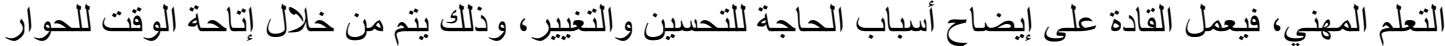

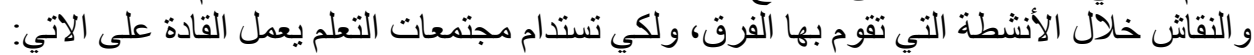

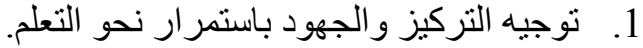
2. الإبقاء على البساطة في طر ح الأفكار وتنفيذها.

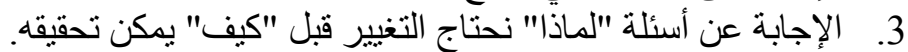
4. التو اصل بفاعلية عن الأولويات.

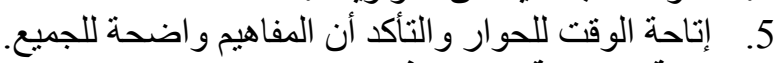

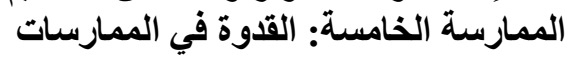

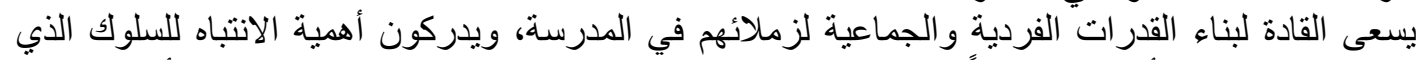

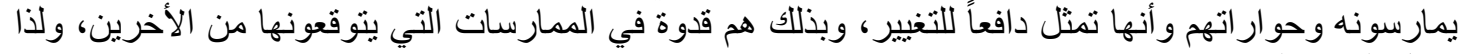

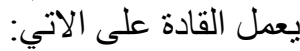
1. الانتباه للأثر الذي تلتركه الحوارات، والقيات القرارات، و الأفعال على الأخرين. 3.

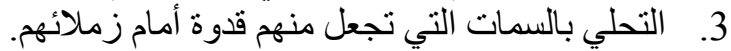
الممارسة السادسة: التأمل في فاعلية القيادة في الذات التات والأخرين

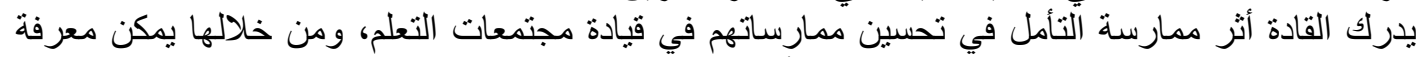

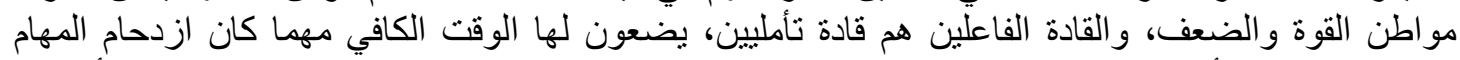

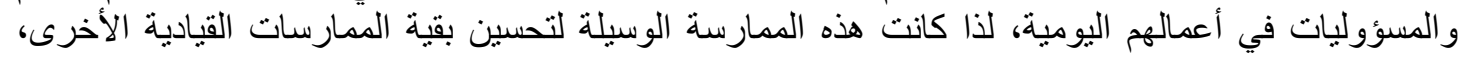

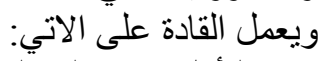

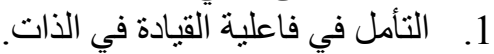
2. التأمل بصورة جماعية في فاعلية القيادة لدى الفرق ألفات أو المدرسة. 3. إعطاء تغذية راجعة للأفر اد و الفرق.

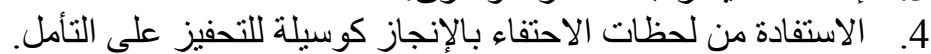

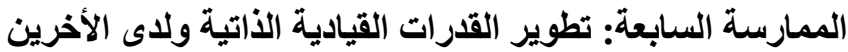

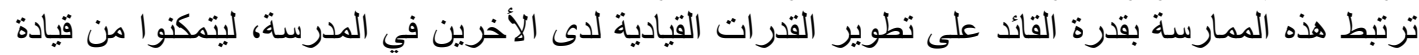

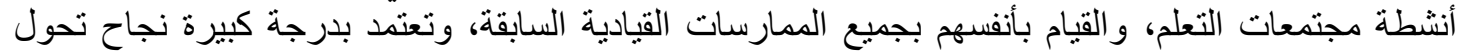

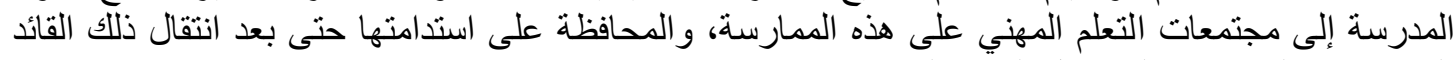

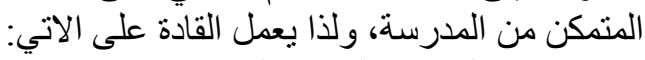
1. تطوير القدرات القيادية الذاتية. 2. 2. تمكين الأخرين من القيام بأدوار قيادية. 3. تحفيز فرص التعلم عن القيادة. وفي دراسة هيت وتكر (Hitt \& Tucker, 2016, pp. 542-559) أجرت الباحثنان مر اجعة لثناثة أطر Ontario للممارسات القيادية في مدارس التعليم العام وهي :إطار منطقة أونتاريو للقيادة المدرسية

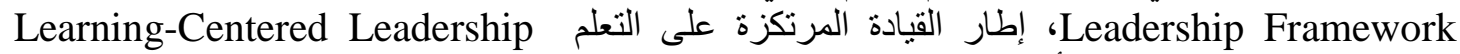

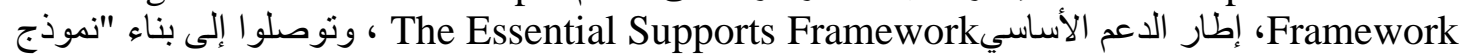
الإطار الموحد Unified Model Framework " للممارسات القيادية الفاعلة التي يقوم بها قادة المدارس ولهاء 


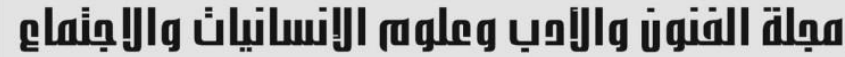

Journal of Arts, Literature, Humanities and Social Sciences www.jalhss.com

أثر على التحصيل الدر اسي للطلاب، ويتكون هذا الإطار من خمس مجالات رئيسية تتضمن على (28) ممارسة

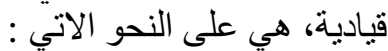

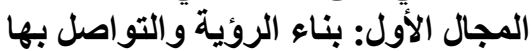

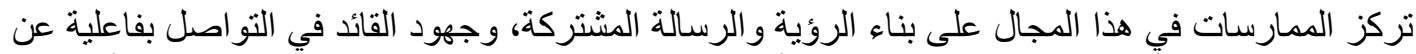

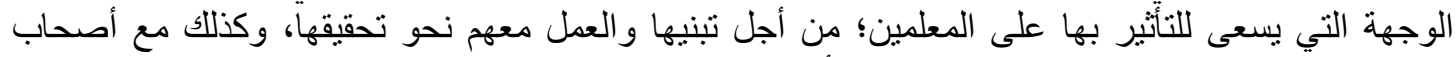

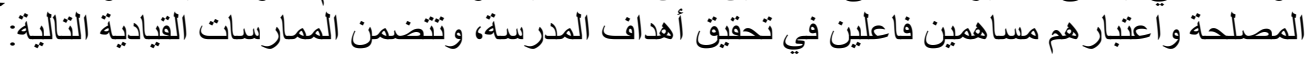

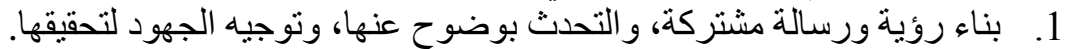
2. وضع أهداف ونوقعات مشتركة عن الأداء. 3. القدوة في الممارسات الأخلاقية والملهمة. 4. التو اصل على نطاق و اسع لحالة الرؤية ومدى تحققها.

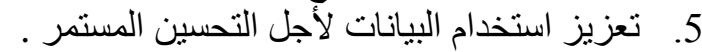
6. الاهتمام بالمحاسبية الخارجية كحافز للتحسين. المجال الثاني: تيسير تجربة تعلم عالية الجودة للطلاب

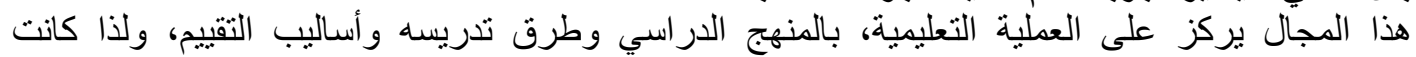

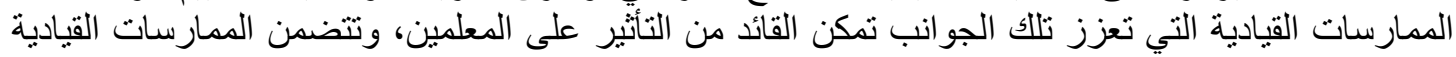

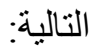

$$
\text { 1 }
$$
2. 3. تطوير المنهج الدر اسي ومتابعته. 4. تطوير طرق التدريس ومتابعتها.

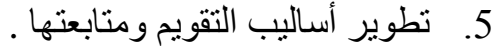
المجال الثالث: بناء القدرة المهنية ترتبط الممارسات القيادية في هذا المجال بتطوير القيات القدرات المهنية، وأحد الجوانب المهمة فيها أن الأنشطة

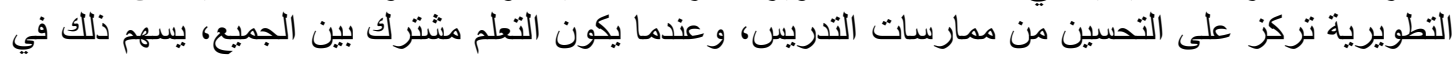
تعزيز ثقة المعلمين بقائد المدرسة كقائد تعليمي، وتتضاتئن التُبن الممارسات القيادية التالية:

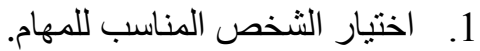
2.

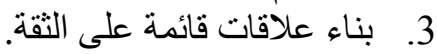
4. توفير فرص التعلم لجميع المعلمين.

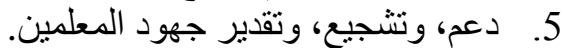
6. ت تعزيز مسؤولية المعلمين في التعلم.

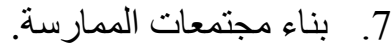

المجال الرابع: بناء المدرسة الماتية الداعمة للتعلم

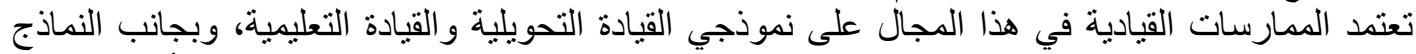

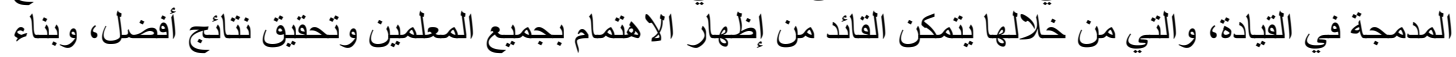

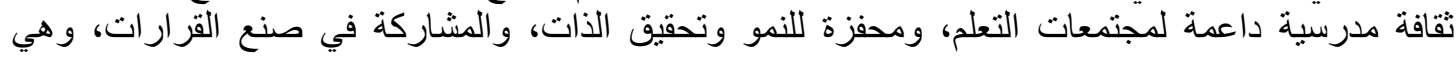
تتضمن الممارسات القيادية التالية: 1. تخصيص المو ارد لأجل تحقيق رؤية ورسالة المدرسة. 2. توظيف الإمكانات المتاحة لأفضل أداء مدكن.

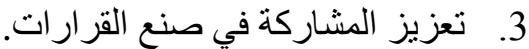

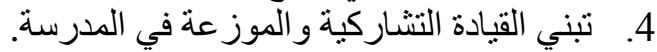
5. 5 مر أعاة التنوع و الاختلافات. 6. المحافظة على التوقعات و المعايير العالية. 7. تحسين ثقافة المدرسة. 


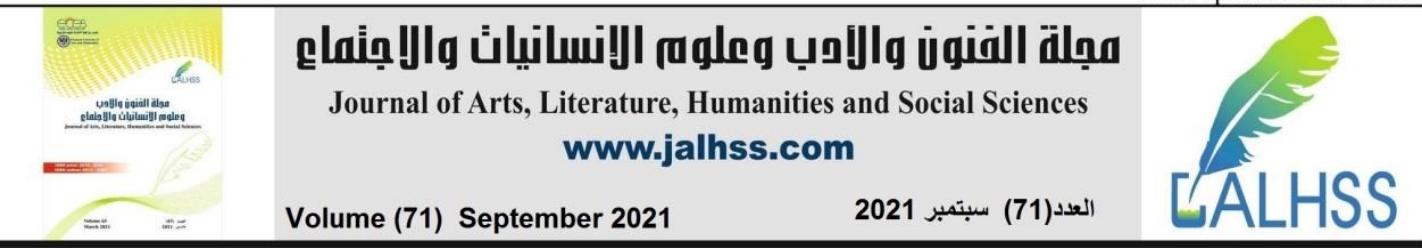

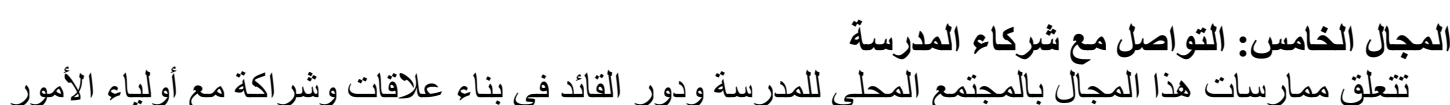

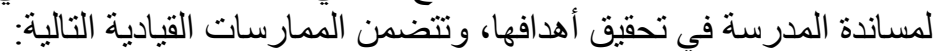

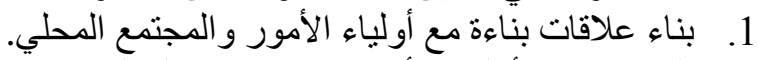

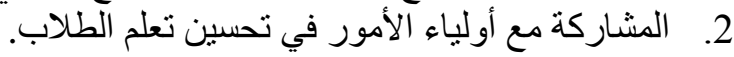
3. توطيد علاقة المدرسة بالمجتمع المحلي.

الار اسات السابقة

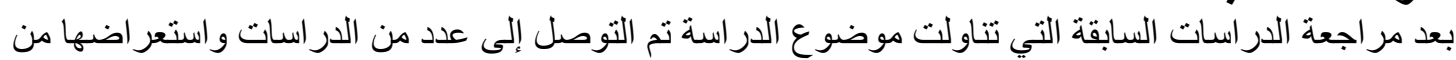
الأقدم إلى الأحدث على النى النحو الاتي:

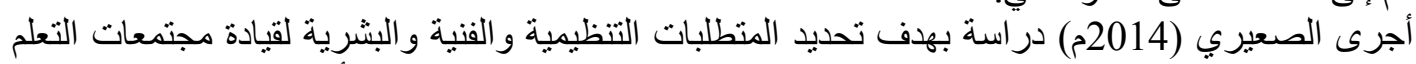

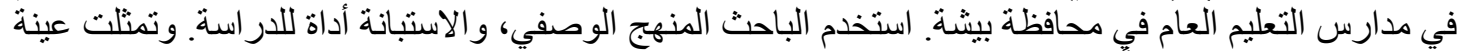

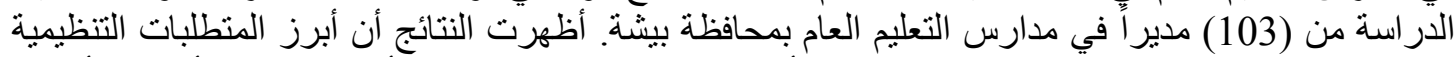

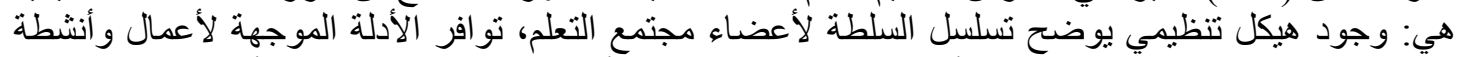

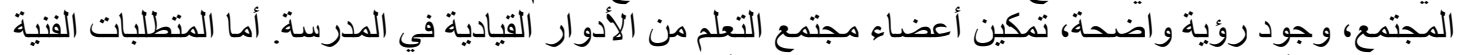

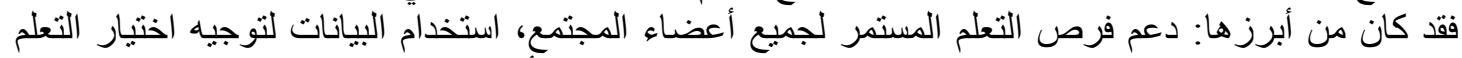

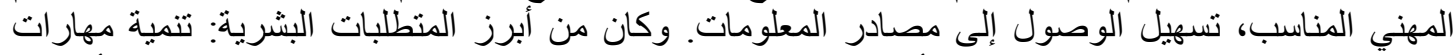

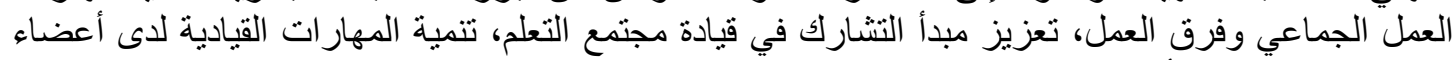

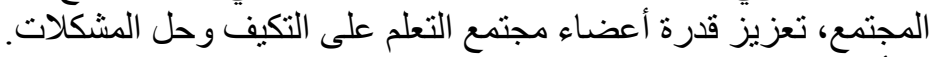

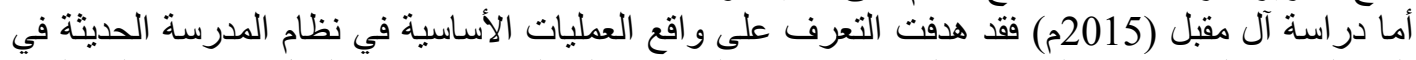

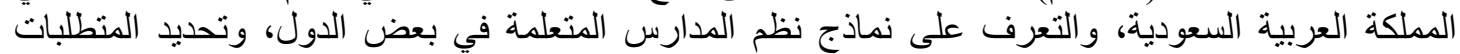

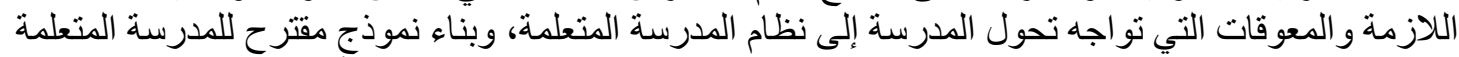

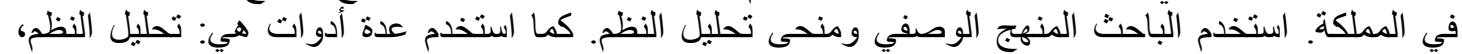

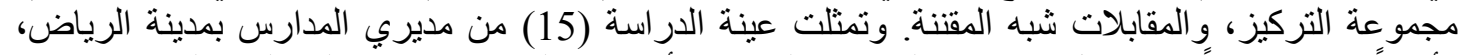

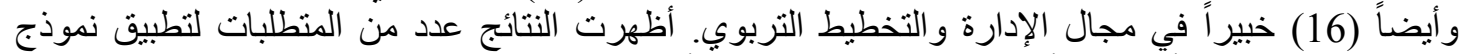

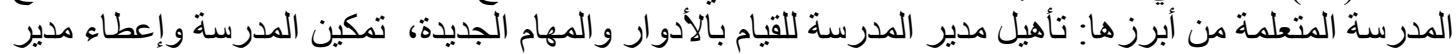

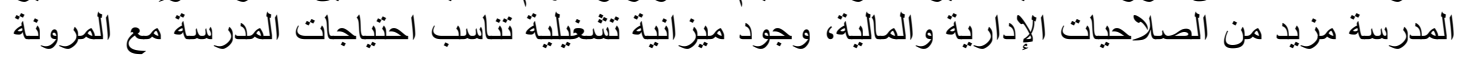

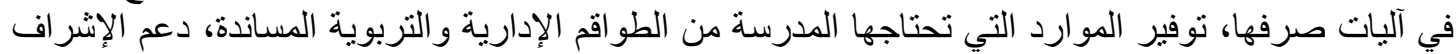

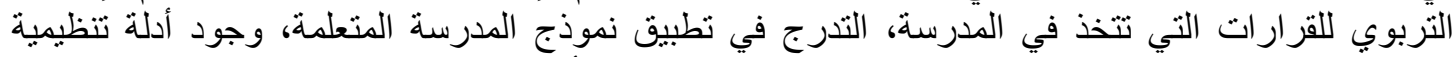

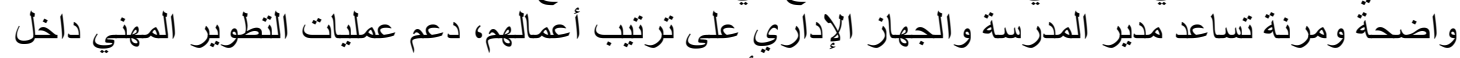

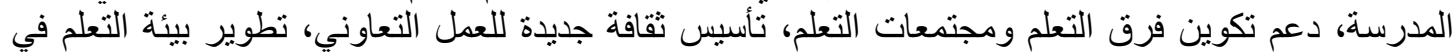
المدرسة و اكتمال تجهيز اتها.

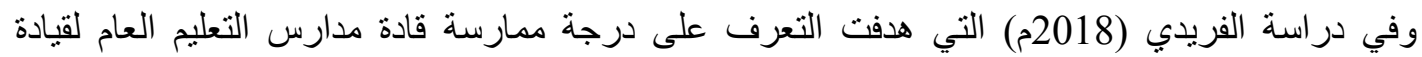

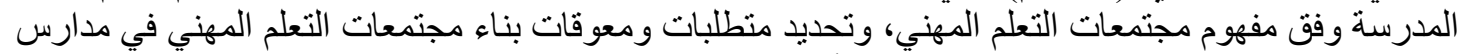

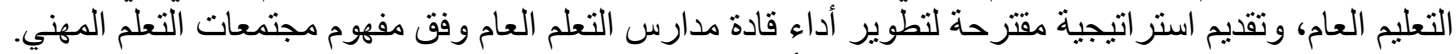

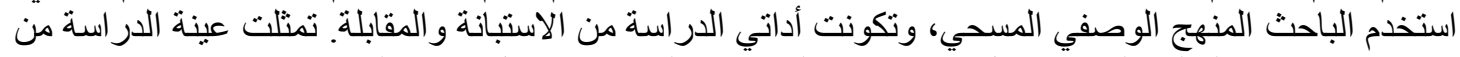

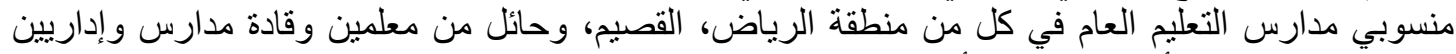

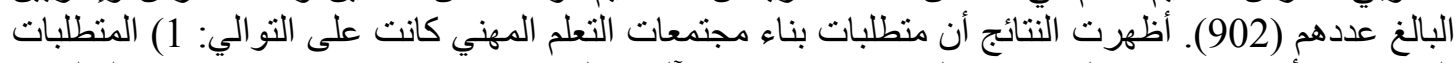

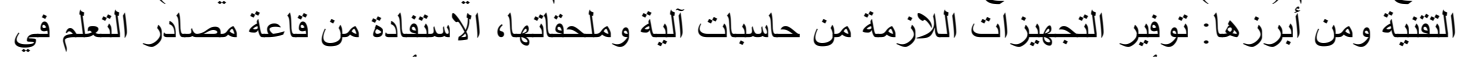

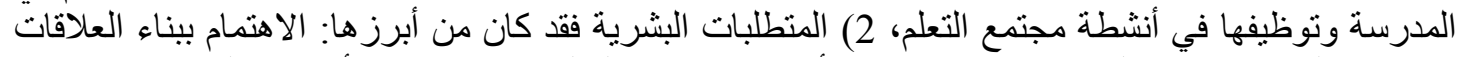

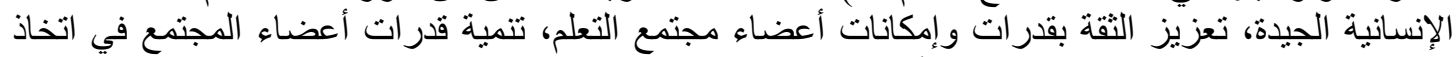

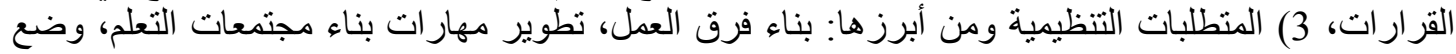




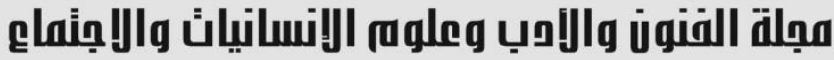 \\ Journal of Arts, Literature, Humanities and Social Sciences www.jalhss.com

كما أجرت الأصقه (2019م) دراسة بهدف التعرف على واقع دور القيادات المدرسية في التطوير المهني

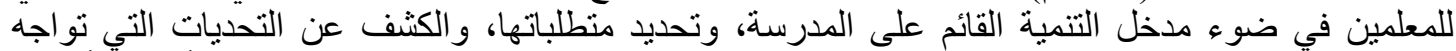
القادة، و التعرف على في بعض النماذج العالمية في التنمية المهنية القائمة على المدرسة، وتهاة وتقديم نموذجاً مقترحاً لدور

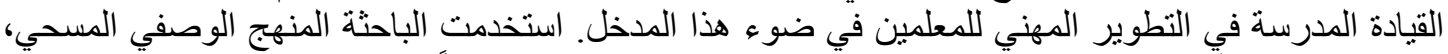

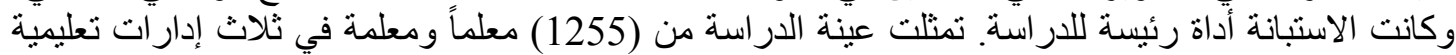

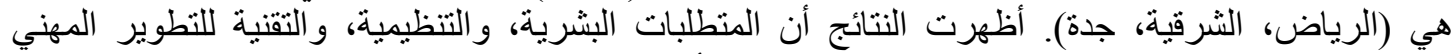
للمعلمين في ضوء هذا المدخل جاءت (بدرجة كبيرة) وأبرز هذه المتطلبات هي: تتمية العلاقات الاجتماعية التهية

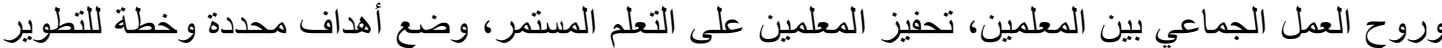

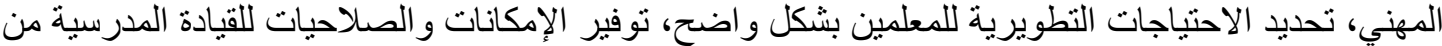

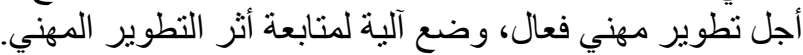
أما در اسة الوهيد وئر الفنتوح (2020م) فقد هدفت إلى تحديد المتطلبات الإدارية و التنظيمية و المادية و الفنية و البشرية اللازمة لتطبيق المنظمة المتعلمة في مدارس مشروع المانة تطوير بمدينة الرياض من وجهة نظر القائدات و المعلمات، و التعرف على الفروق بين إجابات أفر اد الدر اسة حول المتطلبات اللازمة لتطبيق المنيقة المنظمة المتعلمة بمدارس تطوير تعزى لمتغيري (طبيعة العمل، المرحلة الدراسية). استخدم الباحثنان المنهج الوصفي الوفي المسحي، و الاستبانة أداة رئيسة. وتمثلت عيزئة الرينة الدراسة من (40) قائدة ومن (306) معلمة بمدارس تطوير في مدينة

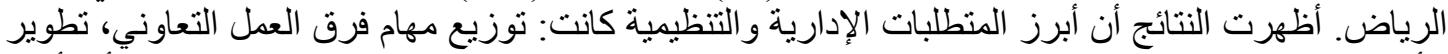

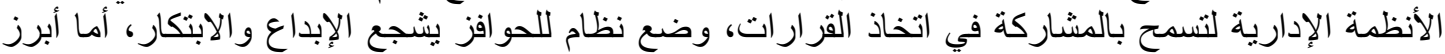

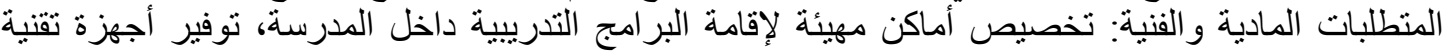
داعمة لعملية التعلم، تجديد المبنى المدرسي ليوفر بيئة محفزة على التعلم، تطبيق بر امج تقنية تسهل عملية التعلم

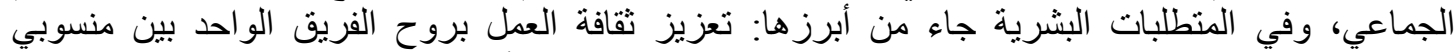
المدرسة، تشجيع تبادل الخبرات و التعلم بين المعلمات، تشجيع تجريب الأفكار الجديدة، تقوية العلاقات الإنسانية بين منسوبي المدرسة، استقطاب المتخصصئ التصنين لتولي مهام التدريب. التعليق على الاراسات السابقة:

اتفقت الدر اسة الحالية مع الدر اسات السابقة في الهدف العام من حيث تحديد المتطلبات التي تمكن قائد المدرسة

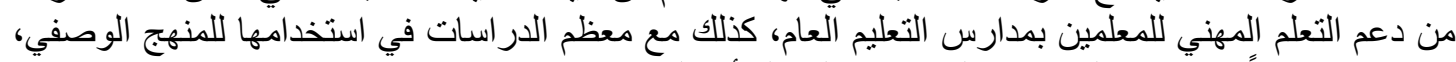

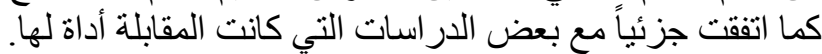

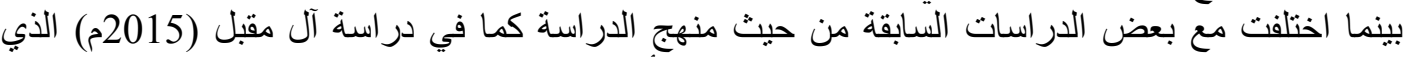

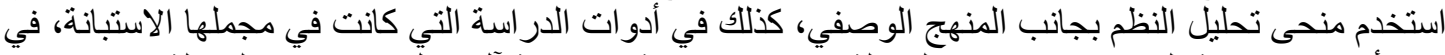

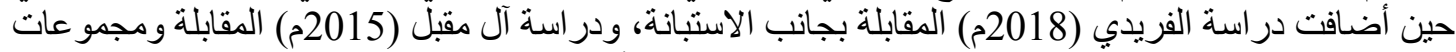

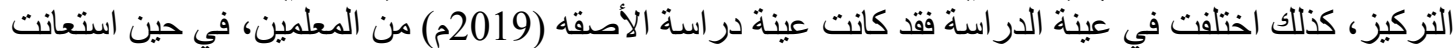
دراسة آل مقبل (2015م) بخبر اء في الإدارة والتخطيط التربوي بجانب قادة المدارس، أما الّهيد هيد والفنتوخ (2020م) فقد كانت العينة من المعلمين وقادة المدارس، في حين استعان الفريدي (2018م) (2015) بعينة من الإداريين

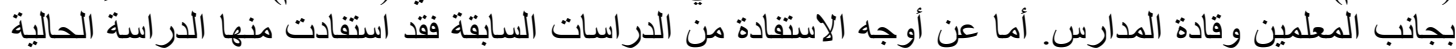

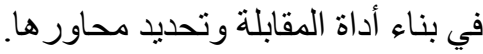

\section{منهجية الار اسة وإجراءاتها: منهج الاراسة:}

استخدمت الدراسة المنهج الوصفي المسحي، و الذي يهدف إلى وصف واقع الظاهرة المر اد دراستها، ومعرفة

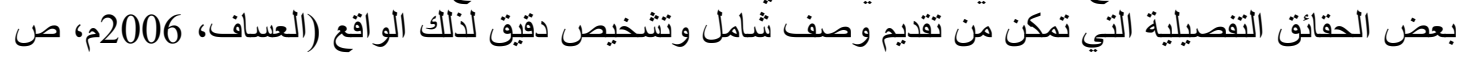
193)، وتم توظيف هذا المنهج لوصف التف المنطلبات اللازمة لتطوير الممارسات القيادية الداعمة للتعلم المهني بمدارس التعليم العام. 


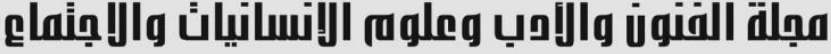

Journal of Arts, Literature, Humanities and Social Sciences www.jalhss.com

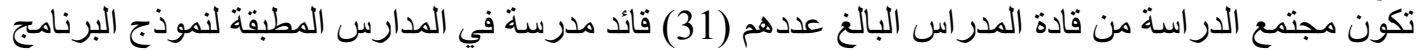

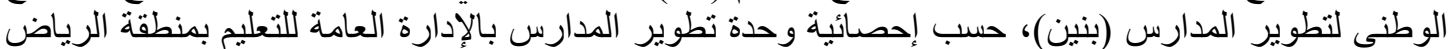

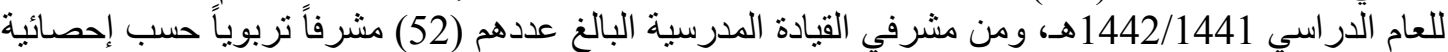

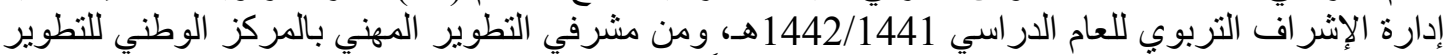

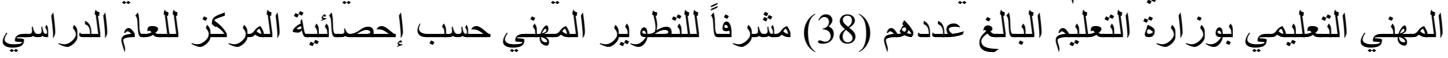

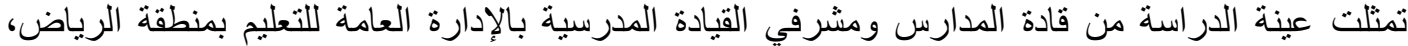

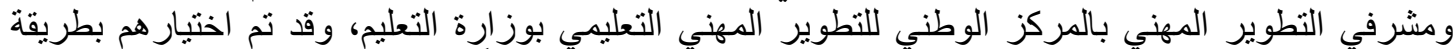

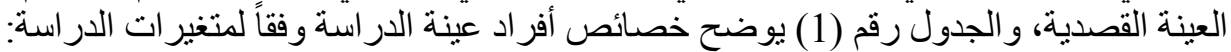

\begin{tabular}{|c|c|c|c|}
\hline \multicolumn{4}{|c|}{ جدول (1) خصائص أفراد عينة الدراسة وفقاً لمتغيرات الدراسة } \\
\hline النسبة & التكرار & الفئة & المتغير \\
\hline$\% 45$ & 9 & قائد مدرسة & \multirow{4}{*}{ طبيعة العمل } \\
\hline$\% 25$ & 5 & مشرف قيادة مدرسية & \\
\hline$\% 30$ & 6 & مشرف تطوير مهني & \\
\hline$\% 100$ & 20 & المجموع & \\
\hline- & - & أقل من 5 سنو ات & \multirow{4}{*}{ سنوات الخبرة في } \\
\hline$\% 5$ & 1 & من 5 إلى 10 سنو ات & \\
\hline$\% 95$ & 19 & أكثر من 10 سنو ات & \\
\hline$\% 100$ & 20 & المجموع & \\
\hline
\end{tabular}

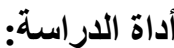

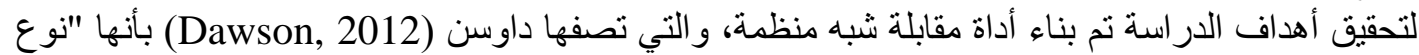

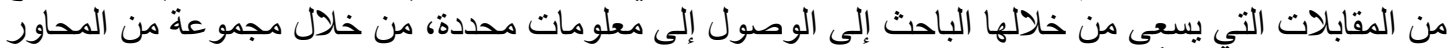

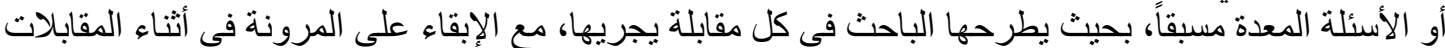

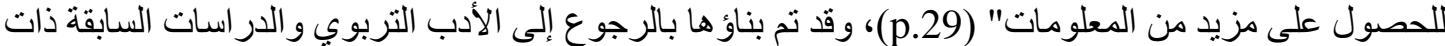

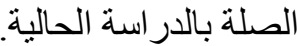

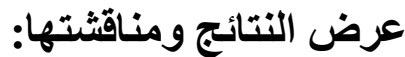
إجابة السؤال الأول: ما المتطلبات التظظيمية اللازمة لتطوير الممارسات القيادية الداعمة للتعلم المهني من

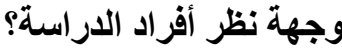
للإجابة عن هذا السؤ ال تم حساب التكر ار ات وات النسب المئوية لإجابات أفر اد الدراسة حول المنطلبات التنظيمية

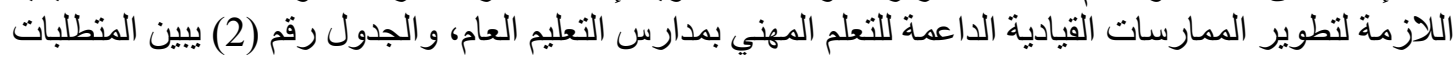

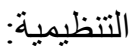

جدول (2) التكرارات والنسب المئوية لإجابات أفراد الدراسة عن المتطلبات التظيمية

\begin{tabular}{|c|c|c|c|}
\hline 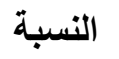 & 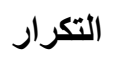 & المتطلبات التنظيمية & p \\
\hline$\% 75$ & 15 & وضع السياسات المنظمة للتعلم المهني بمدارس التعلم العام & 1 \\
\hline$\% 75$ & 15 & نشر ثقافة التعلم المهني & 2 \\
\hline$\% 60$ & 12 & تمكين المدرسة ودعم قرار اتها ومبادر اتها في التعلم المهني & 3 \\
\hline$\% 50$ & 10 & التدرج في تغيير ثقافة المدرسة نحو التعاون و العمل الجماعي & 4 \\
\hline
\end{tabular}




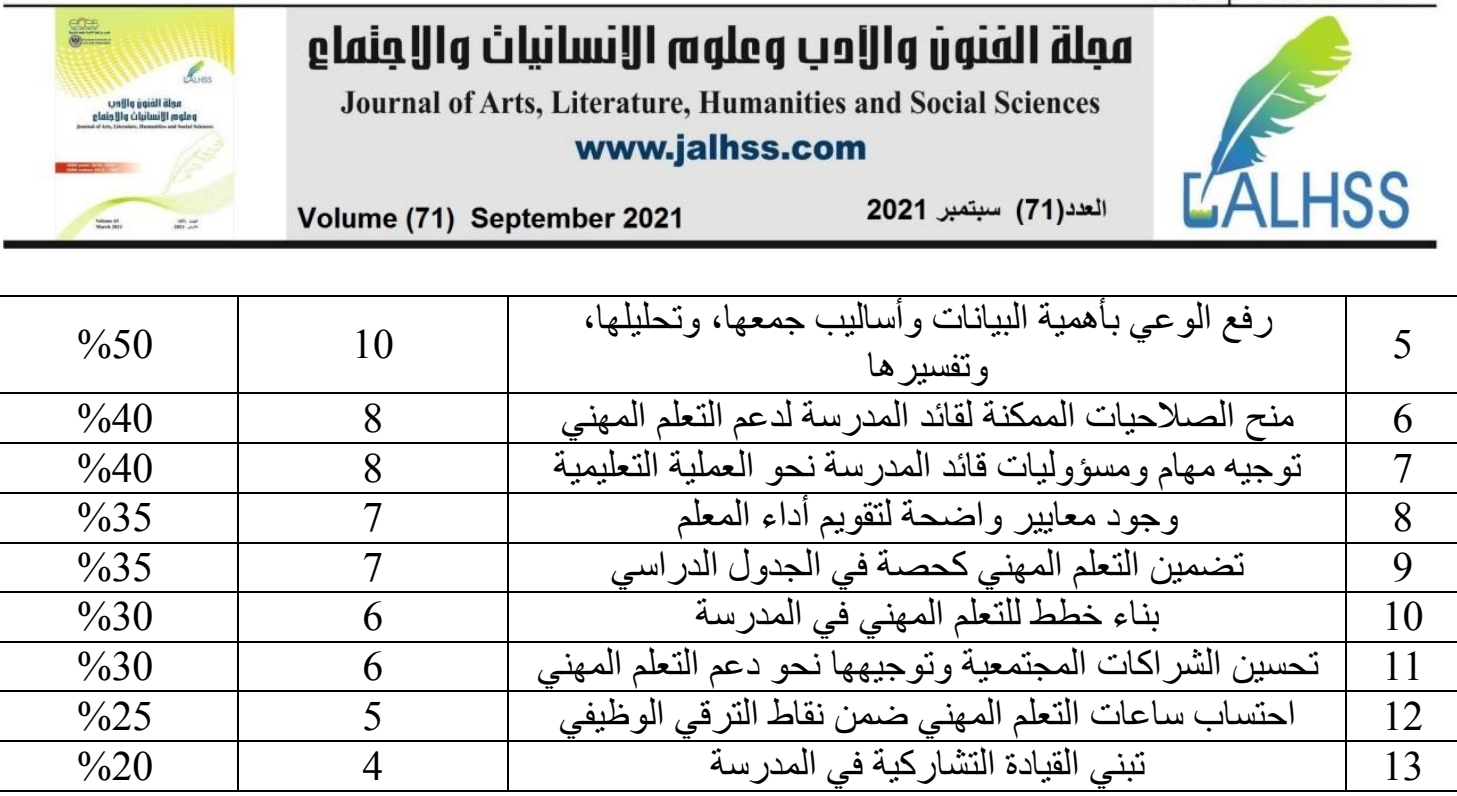

يتضح من الجدول رقم (2) أن نسبة أعلى تكر ار في المتطلبات التنظيمية اللازمة لتطوير الممارسات القيادية

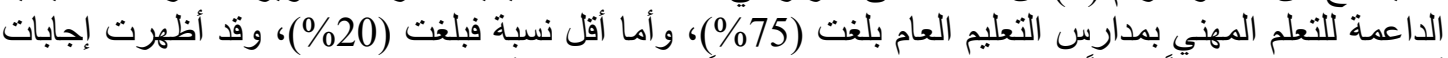

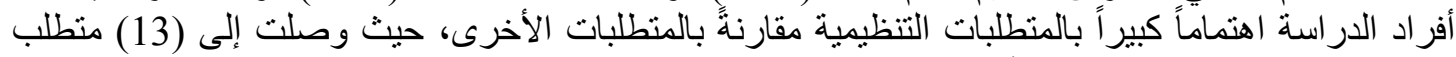

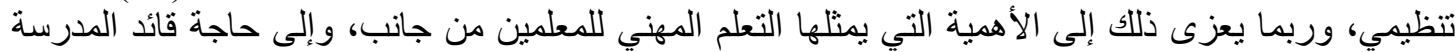

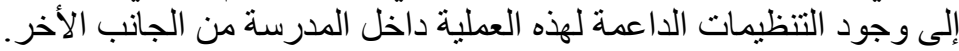

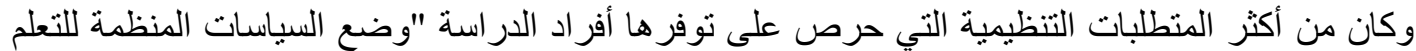

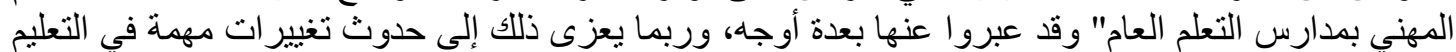

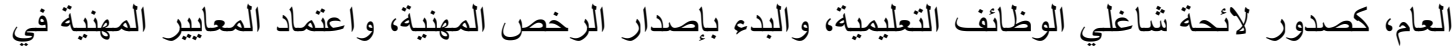

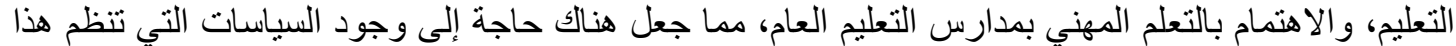

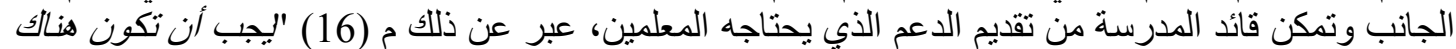

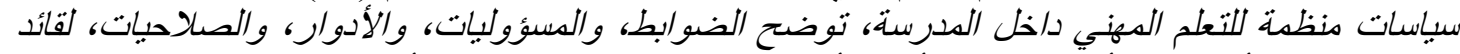

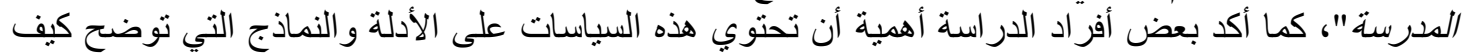

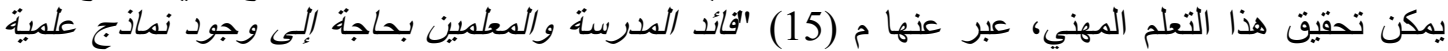

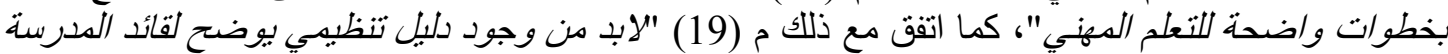

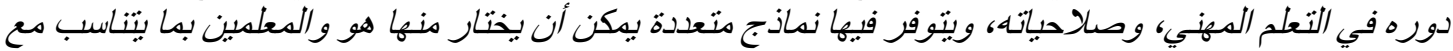

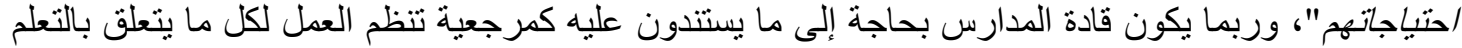

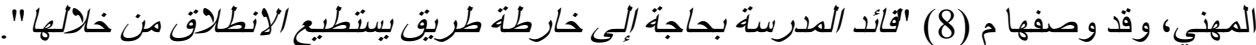

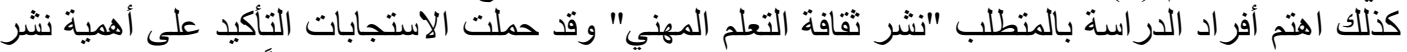

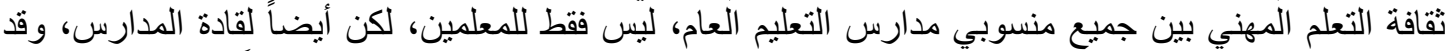

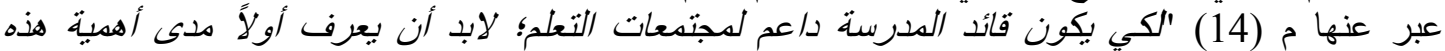

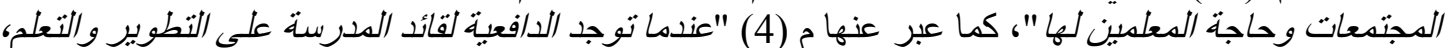

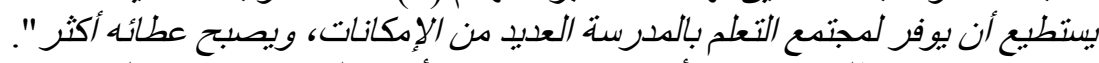

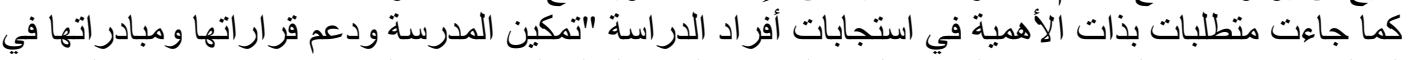

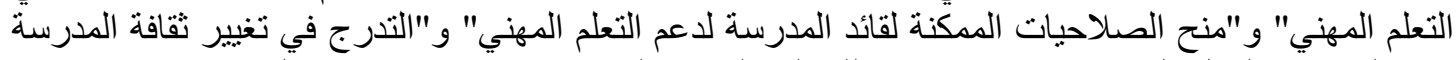

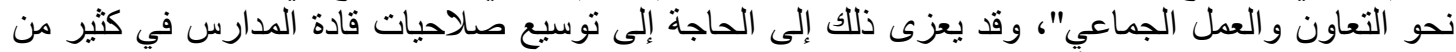

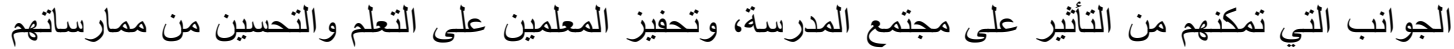

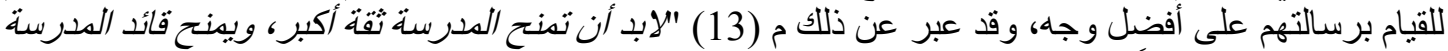

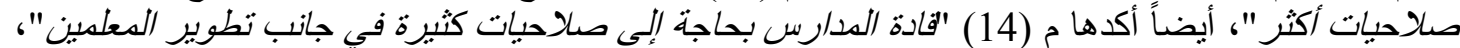

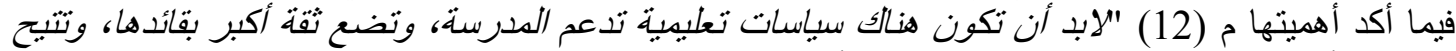

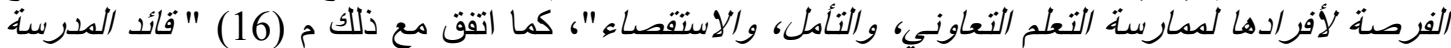

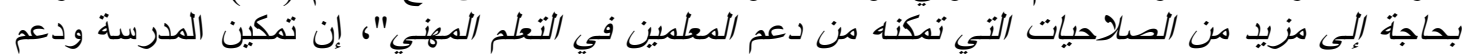

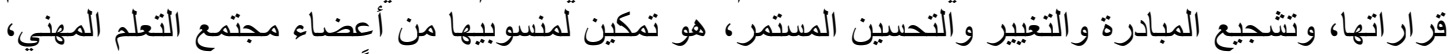

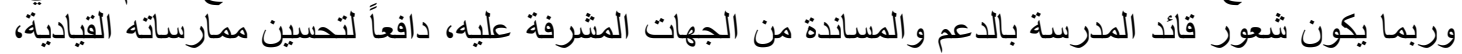




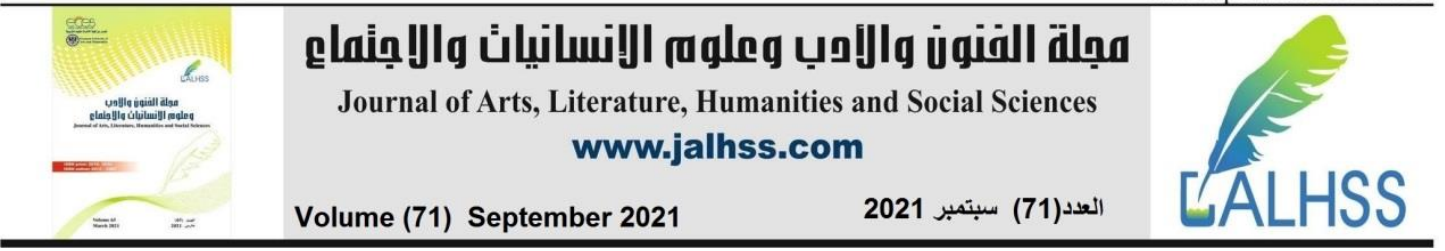

يعبر عنها م (10) "عندما بشعر قائد الددرسة بأن العيدان التعليهي مساند له بالدرجة الأولى يصبح أكثر إقبالاً

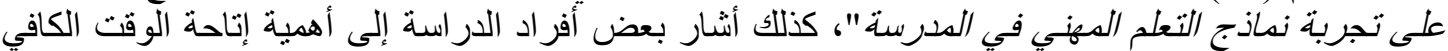

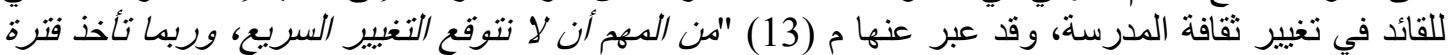

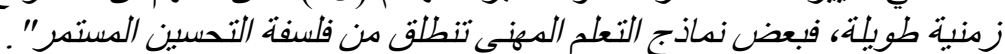

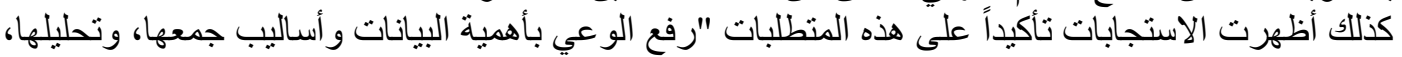

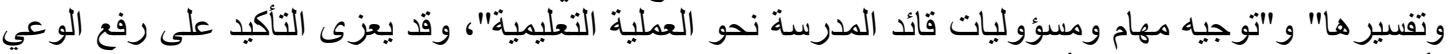

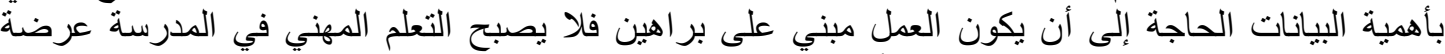

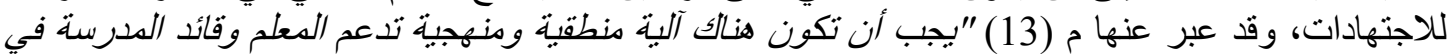

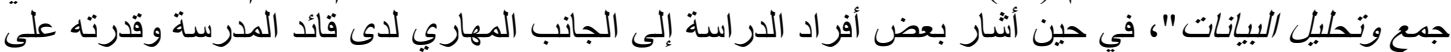

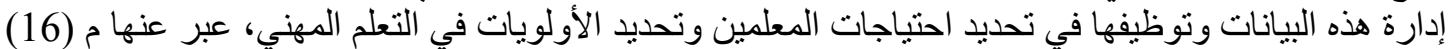

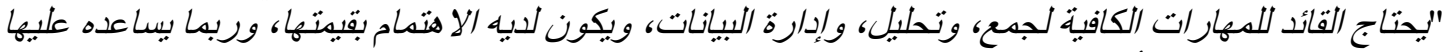

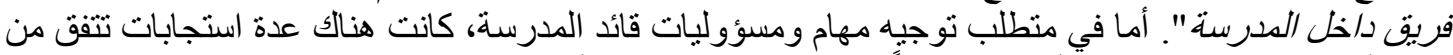

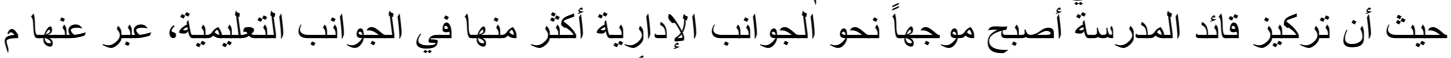

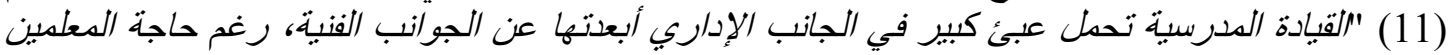

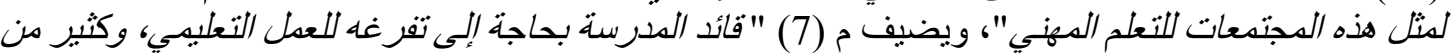

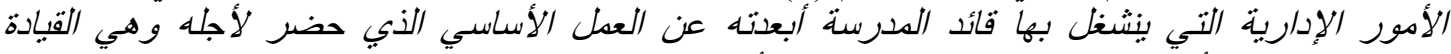

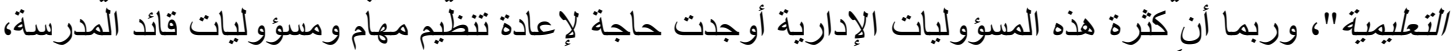

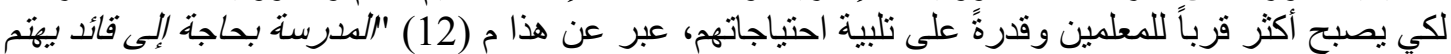

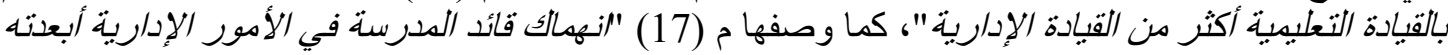

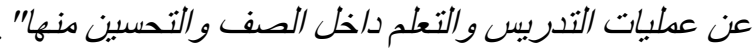

أما في جانب إيجاد الوقت للتعلم المهني، فقد كان متطلب "لإن التضمين التعلم المهني كحصة في الجدول

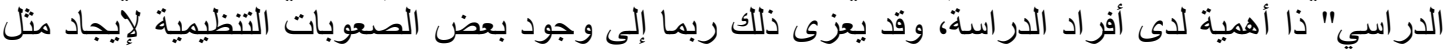

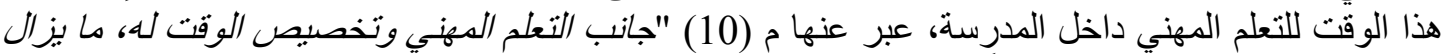

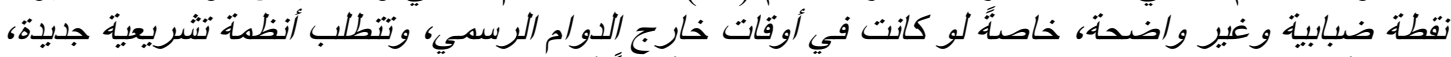

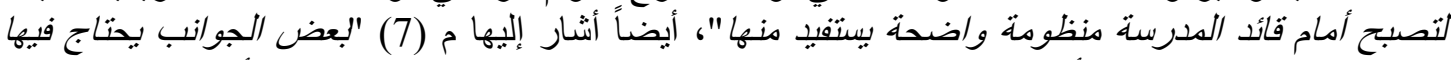

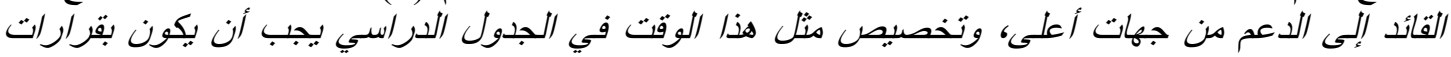

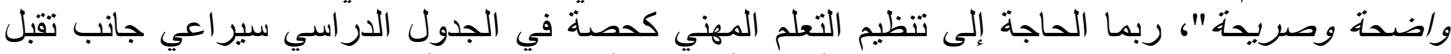

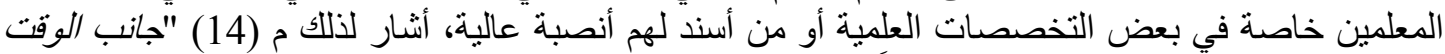

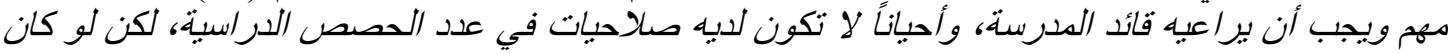

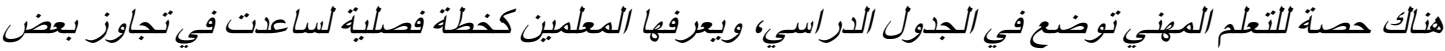

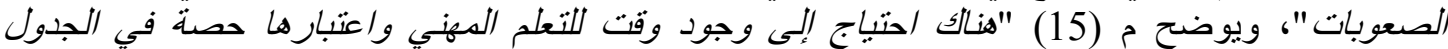

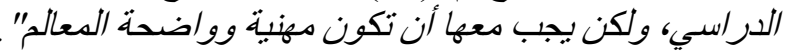

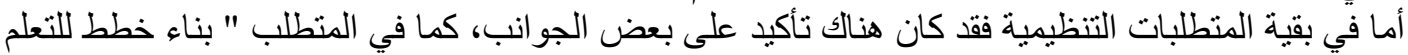

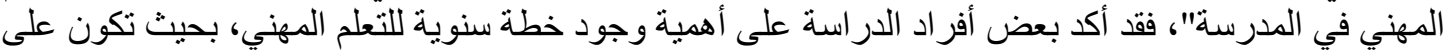

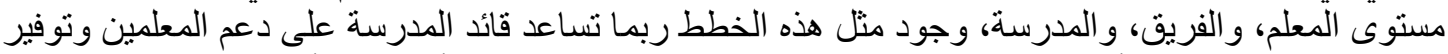

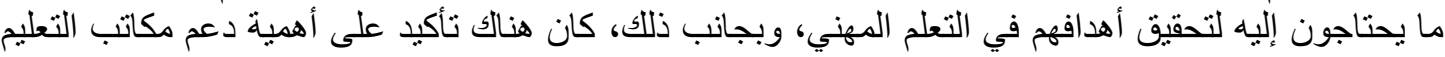

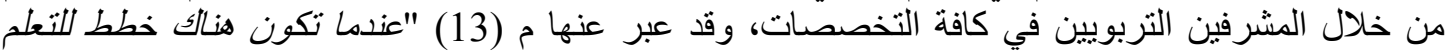

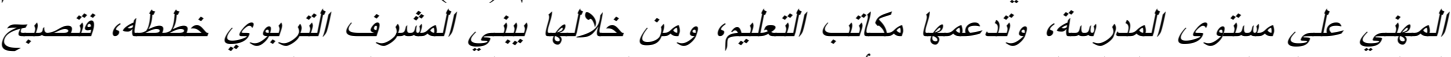

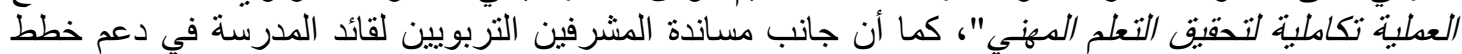

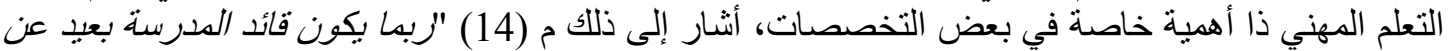

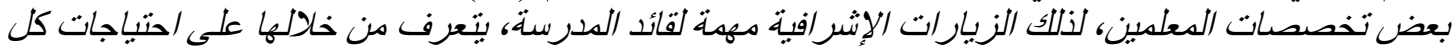

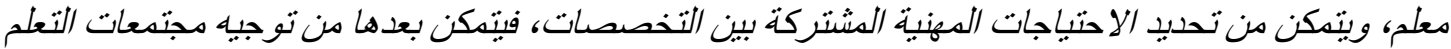

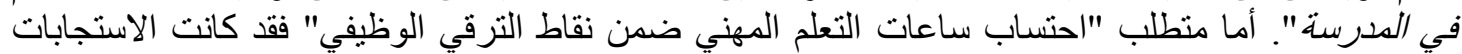
تبين ضرورة وجود آلية لاحتساب هذه الساعات التي يقضيها المعلمين في التعلم المهني، وكيف سيتمكن قائد 


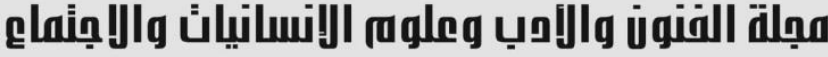

Journal of Arts, Literature, Humanities and Social Sciences www.jalhss.com

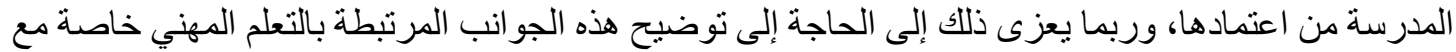

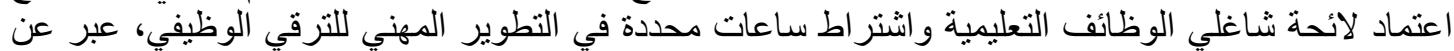

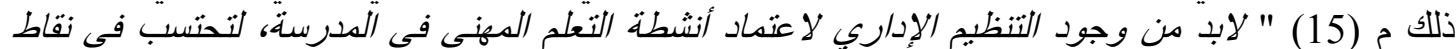

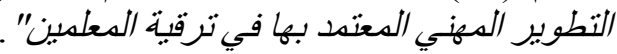

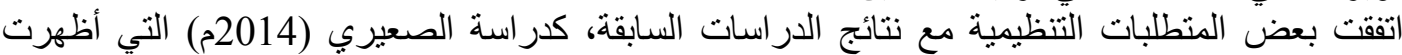
أهمية تعزيز مبدأ التشارك في القيادة كمتطلب لقيادة مجتمعات التعلم. كذلك مع دراسة آل مقبل (2015م) التي

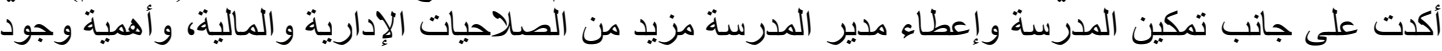

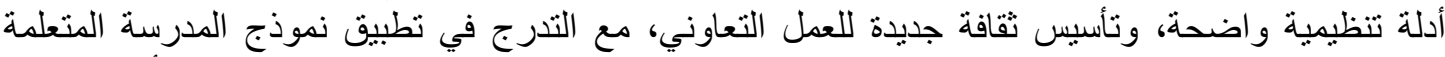
كمنطلبات عند التحول إلى نظام المدرسة المتعلمة. كذلك مع در اسة الفريدي (2018م) التي بينت أهمية وضعات وضع

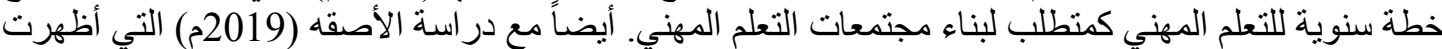
أهمية وضع أهداف محددة وخطة للتطوير المهني، و إعطاء الصصلاحيات للقيادة المدرسية من أجل تطوير مهني

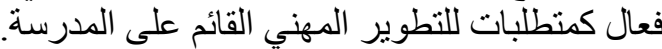

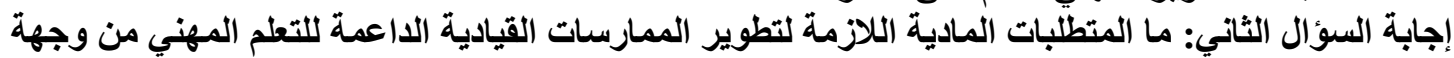

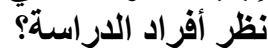
للإجابة عن هذا السؤال تم حساب التكرارات الت والنسب المئوية لإجابات أفر اد الدراسة حول المتطلبات المادية

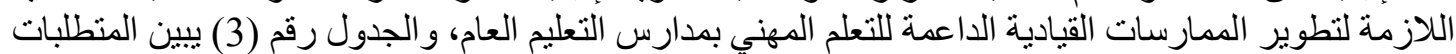
المادية:

جدول (3) التكرارات والنسب المئوية لإجابات أفراد الاراسة عن المتطلبات المادية

\begin{tabular}{|c|c|c|c|}
\hline 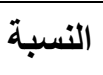 & 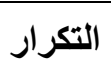 & المتطلبات المادية & م \\
\hline$\% 85$ & 17 & بناء قاعدة بيانات متكاملة عن مجتمع المدرسة & 1 \\
\hline$\% 75$ & 15 & وجود حو افز مادية ومعنوية تشجع التعلم المهني & 2 \\
\hline$\% 60$ & 12 & توفر القاعة والتجهيزات التقنية اللازمة للتعلم المهني & 3 \\
\hline$\% 55$ & 11 & تخصيص بنود للتعلم المهني في الميز انية التشغيلية للمدرسة & 4 \\
\hline$\% 40$ & 8 & اكتمال التجهيز ات و البنية التحتية للمدرسة & 5 \\
\hline$\% 35$ & 7 & توفر أدوات تحديد الاحتياجات المهنية وقياس أثر التعلم المهني & 6 \\
\hline$\% 35$ & 7 & تصميم منصة رقمية للتعلم المهني & 7 \\
\hline
\end{tabular}

يتضح من الجدول رقم (3) أن نسبة أعلى تكر ار في المتطلبات المادية لتطوير الممارسات القيادية الداعمة للتعلم المهني بمدارس التعليم بلغت (85\%)، و أما أقل نسبة فبلغت (35\%)، وقد وصن وصل عدد المتطلبات المادية

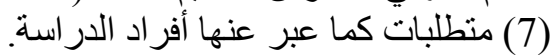

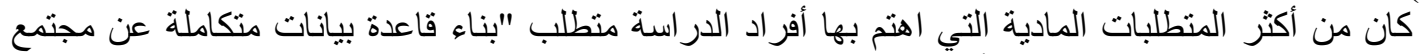

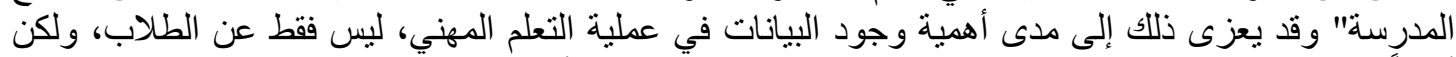

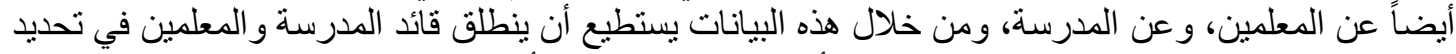
احتياجات التعلم المهني، ووضع الخطط، وقياس أثر التعلم المهني على أداء المعلمين، و وعلى تحسن تعلم طلابهه، وقد عبر عن أهميتها م (10) "الاهتمام بالبيانات بجب أن تكون حاضرة من بدابة العام الدراسي، وأن تكون

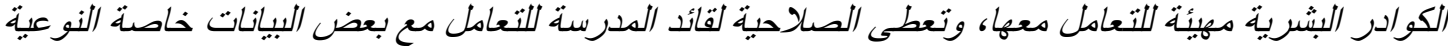

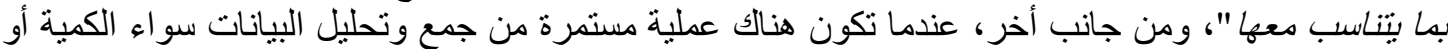

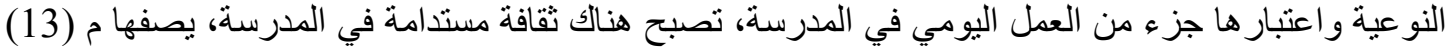

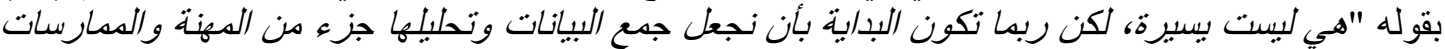

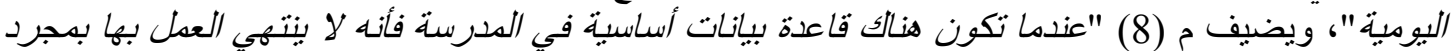

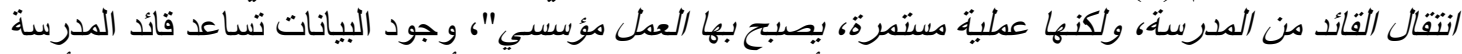

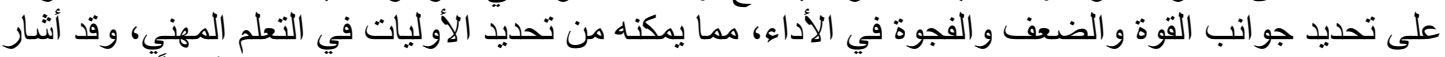

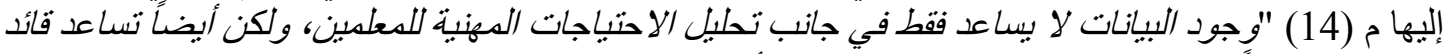

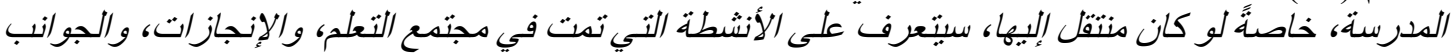




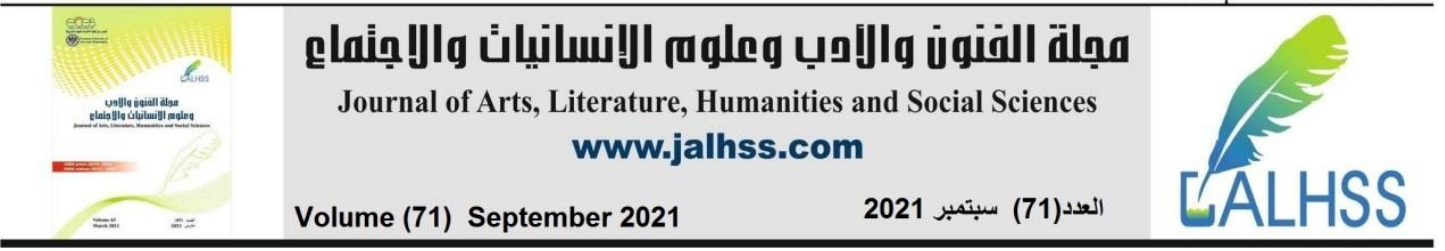

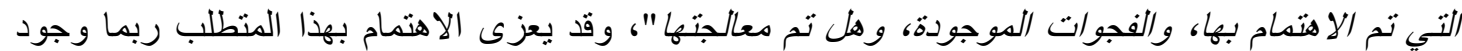

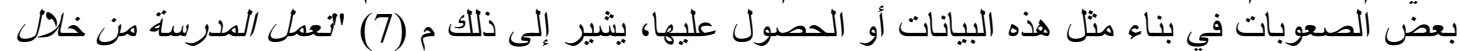

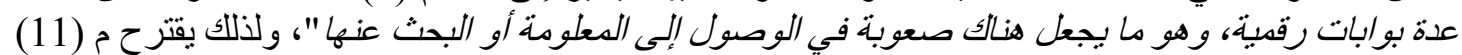

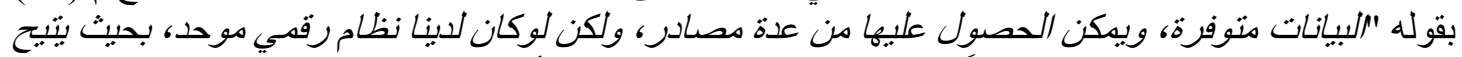

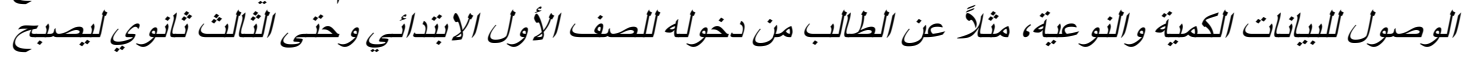

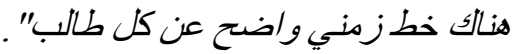

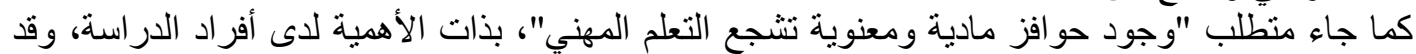

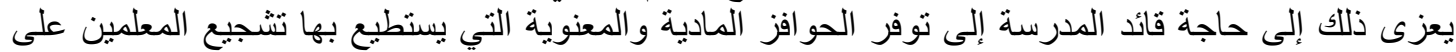

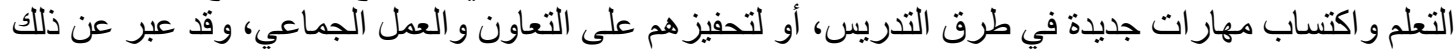

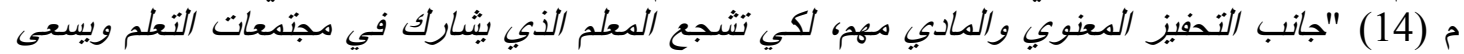

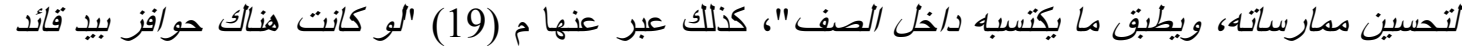

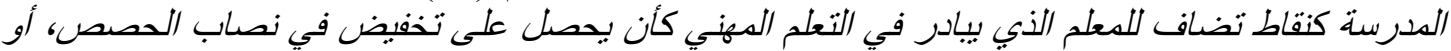

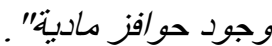

أما المتطلبان "توفر القاعة والتجهيزات التقنية اللازمة للتعلم المهني" و "اكتمال التجهيزات و البنية التحتية

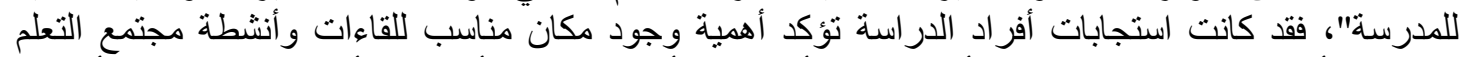

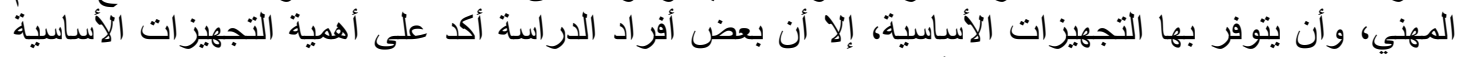

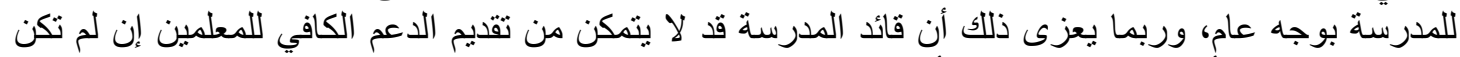

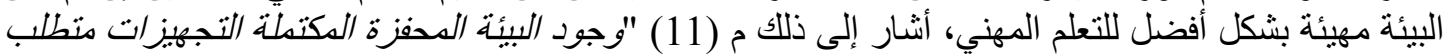

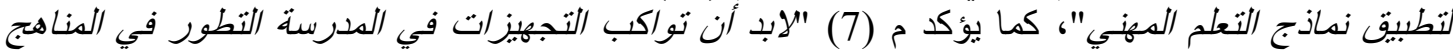

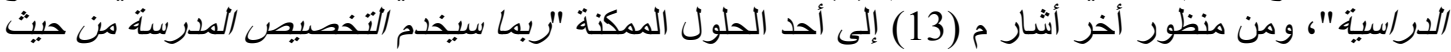

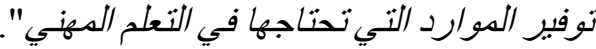

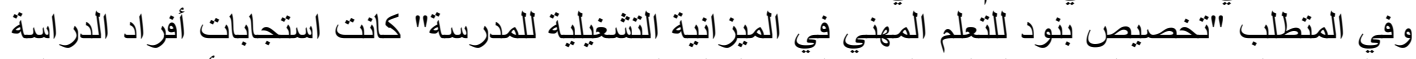

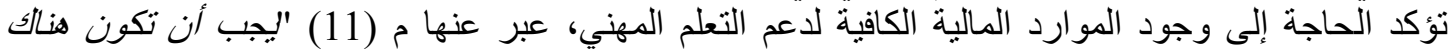

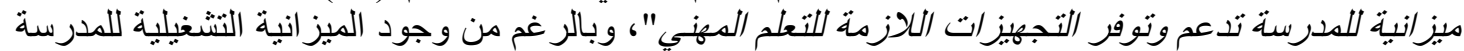

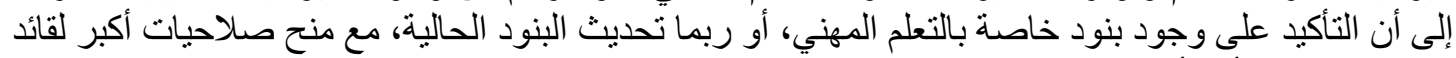

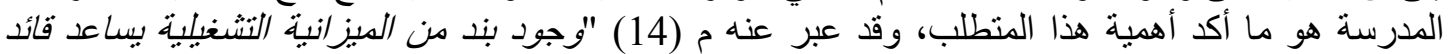

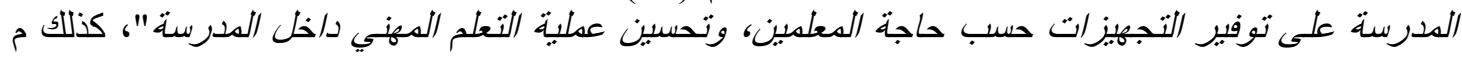

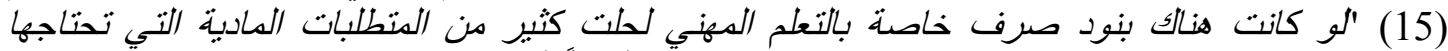

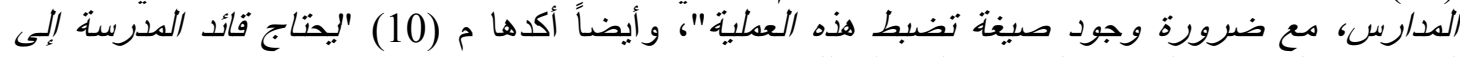

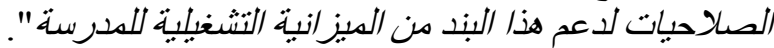

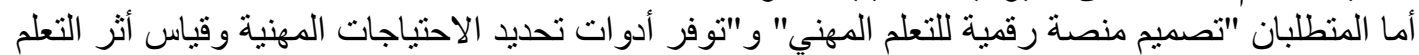

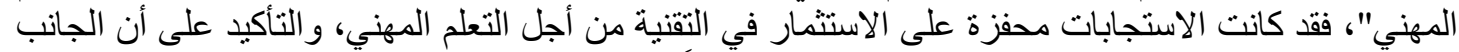

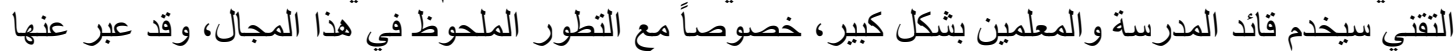

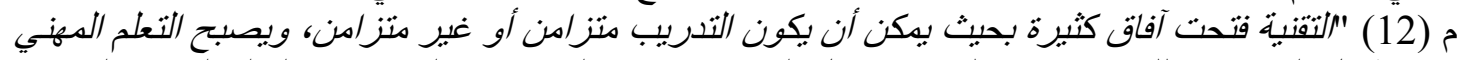

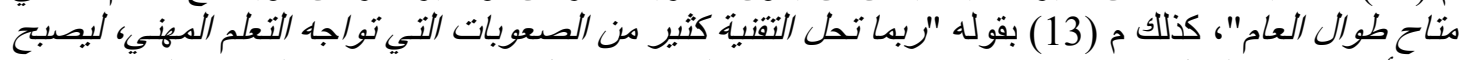

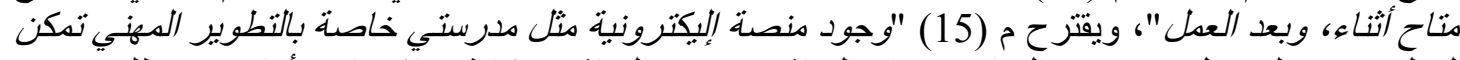

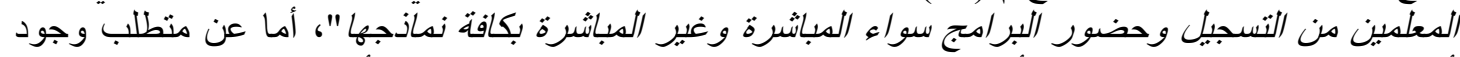

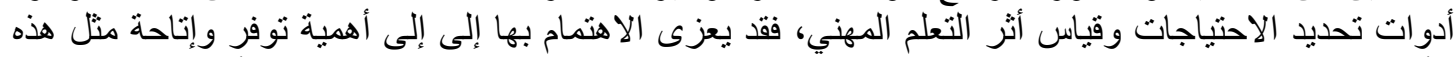

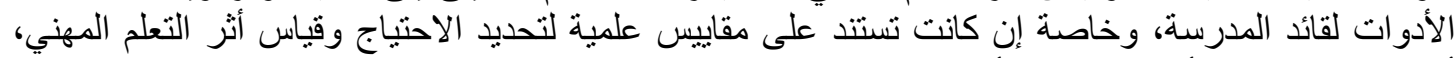

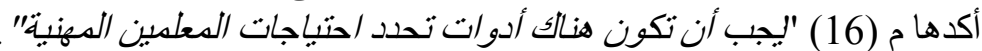

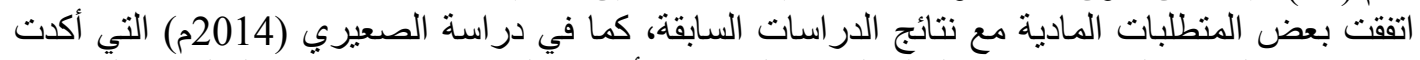

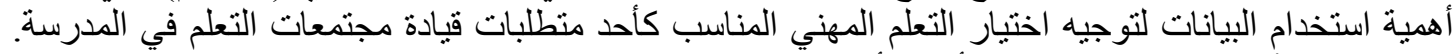

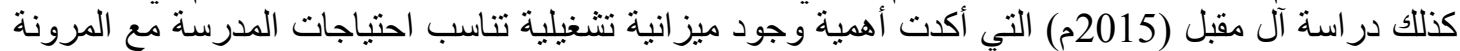
في آليات صرفها، وتطوير بيئة التحلم في المدرسة و اكتمال تجهيزاتها كمنطلبات للتحول إلى نظام المدرسة المنة 


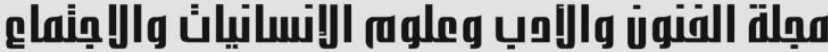

Journal of Arts, Literature, Humanities and Social Sciences www.jalhss.com

المتعلمة. كذللك في دراسة الفريدي (2018م) التي أظهرت أهية نوفير التجهيزات اللازمة من الحواسيب

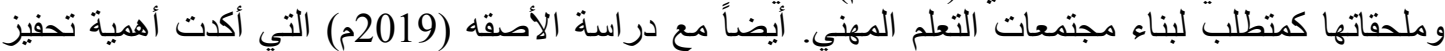

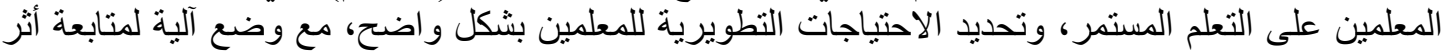

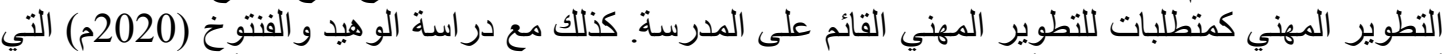

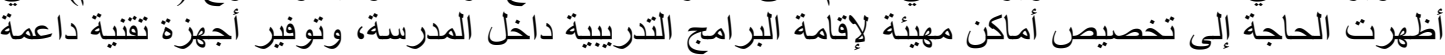

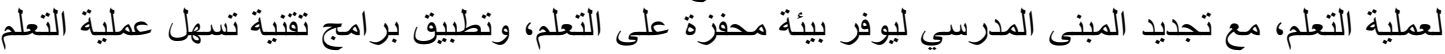

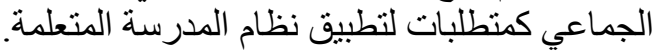
إجابة السؤال الثالث: ما المتطلبات البشرية اللازمة لتطوير الممارسات القيادية الداعمة للتعلم المهني من

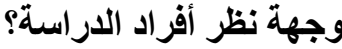

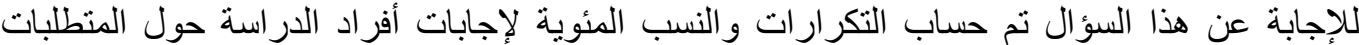

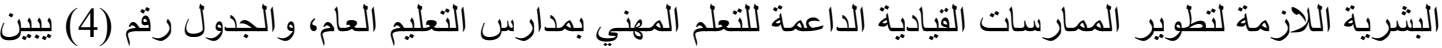

جدول (4) التكرارات والنسب المئوية لإجابات أفراد الدراسة عن المتطلبات البشرية

\begin{tabular}{|c|c|c|c|}
\hline 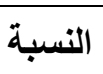 & 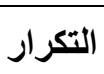 & المتطلبات البشرية & r \\
\hline$\% 70$ & 14 & تأهيل قائد المدرسة على قيادة التعلم المهني في المدرسة & 1 \\
\hline$\% 50$ & 10 & بناء فريق التعلم المهني في المدرسةّ & 2 \\
\hline$\% 50$ & 10 & توفر الكو ادر الإدارية المساندة لقائد المدرسة وتأهيلها & 3 \\
\hline$\% 40$ & 8 & وجود منسقين للتعلم المهني على مستوى المدرسة & 4 \\
\hline$\% 40$ & 8 & استقطاب الخبر اء من خارج المدرسة & 5 \\
\hline$\% 25$ & 5 & اكتمال التتكيلات المدرسية و التعليمية في جميع التخصصات & 6 \\
\hline
\end{tabular}

يتضح من الجدول رقم (4) أن نسبة أعلى تكرار في المتطلبات البشرية اللازمة لتطوير الممارسات القيادية

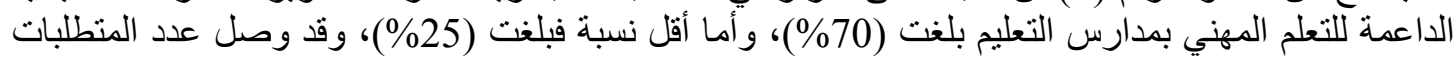
البشرية (6) منطلبات كما عبر عنها أفر الد الدئ الدراسة.

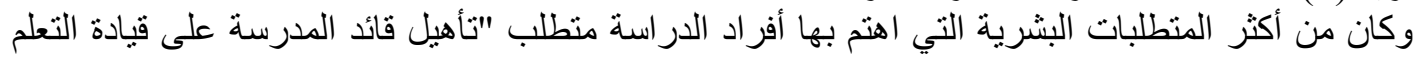

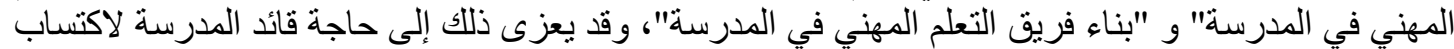

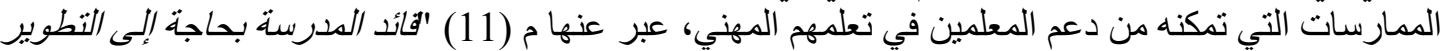

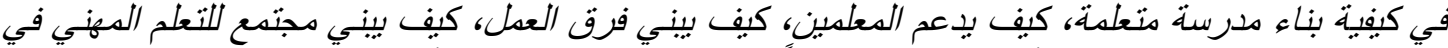

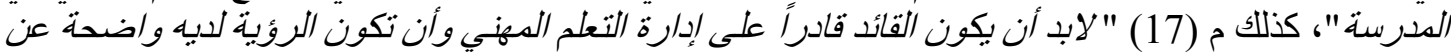

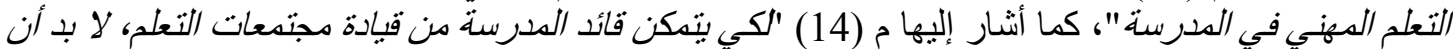

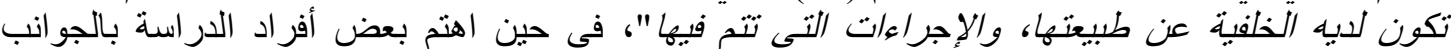

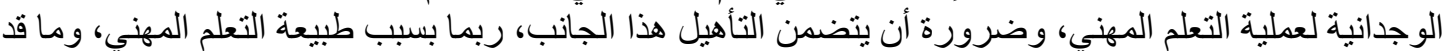

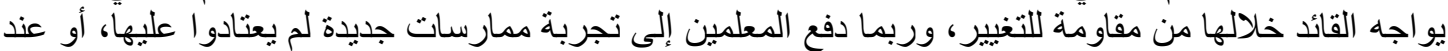

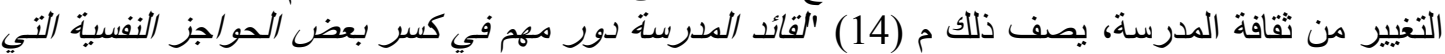

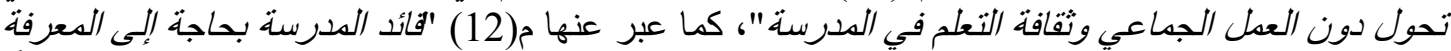

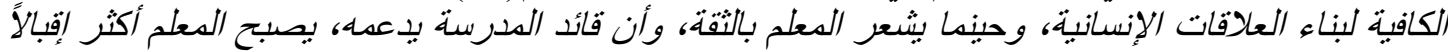

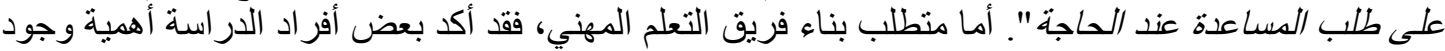

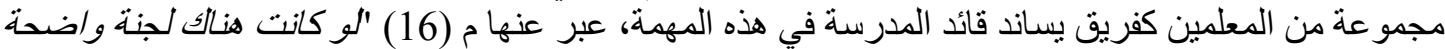

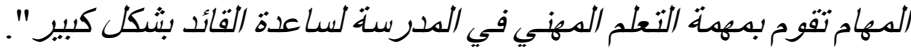

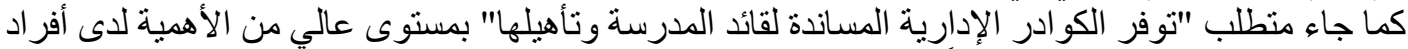

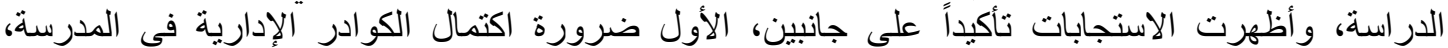

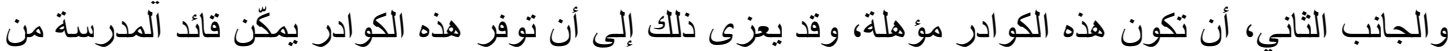

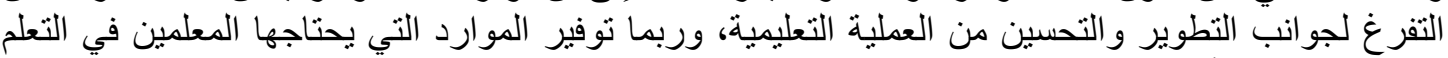

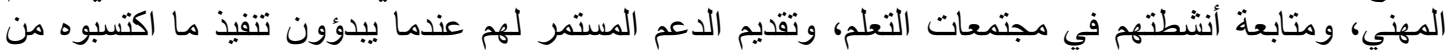




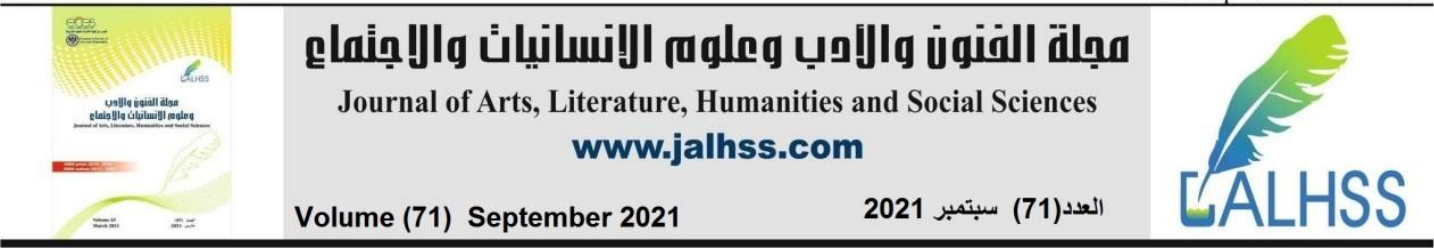

معارف ومهارات داخل الصف، وقد عبر عن ذلك م(10) "الأعباء التنفيذية البيومية، وضعف الكوادر البشرية التبرية

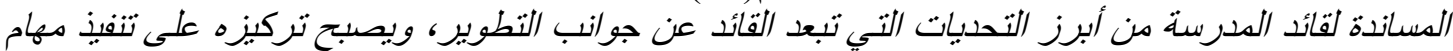

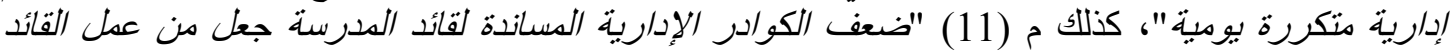

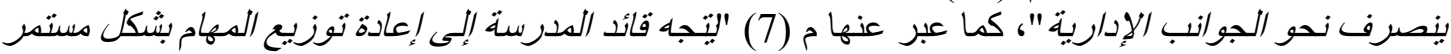

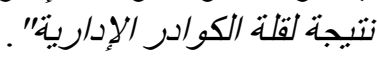

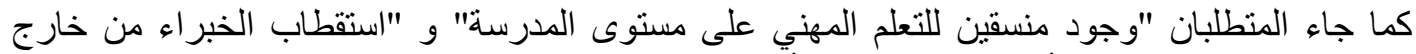

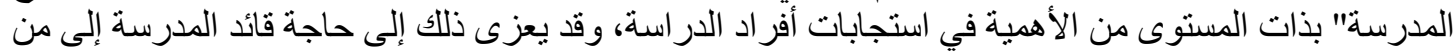

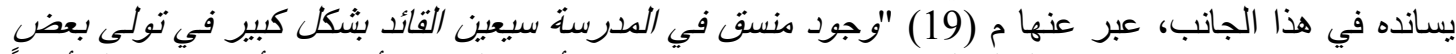

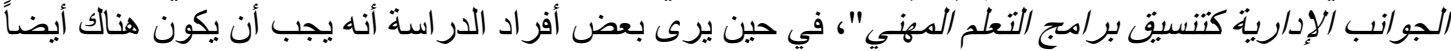

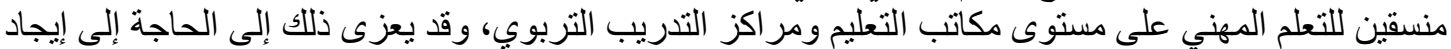

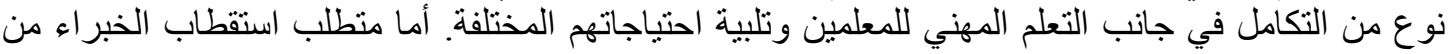

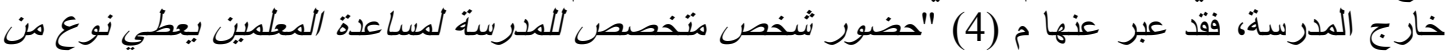

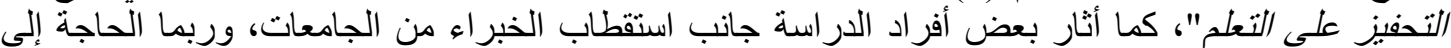

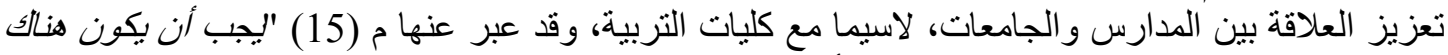

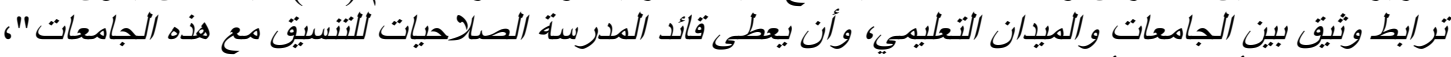

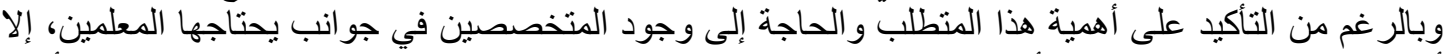

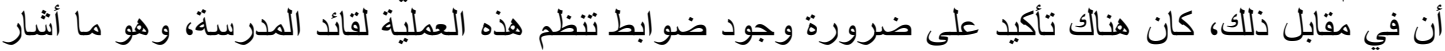

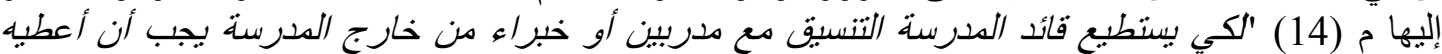

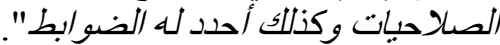

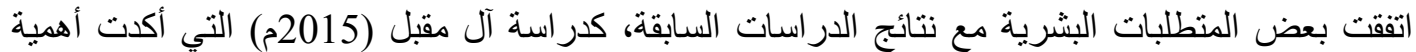

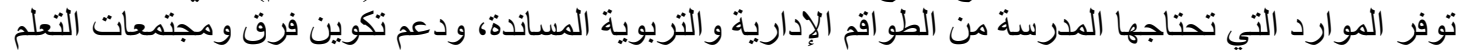

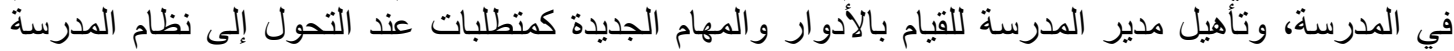

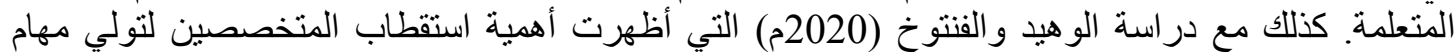
التدريب كمنطلبات لتطبيق نظام المدرسة المتعلمة.

\section{نتائج الار اسة وتوصياتها أولاً: نتائج الأراسة الدة

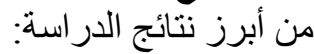

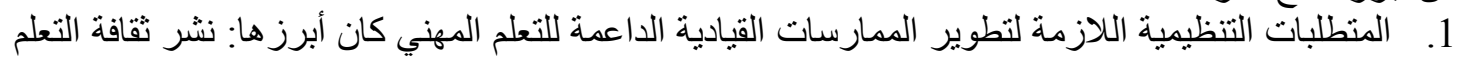

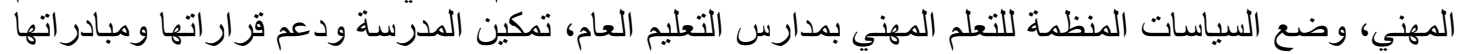

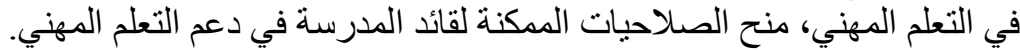

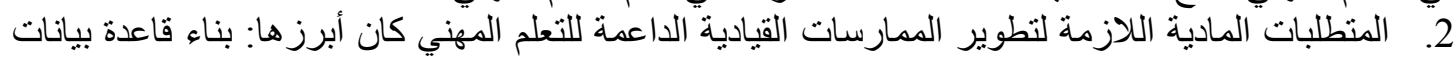

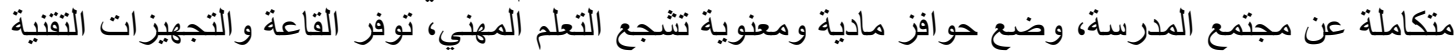

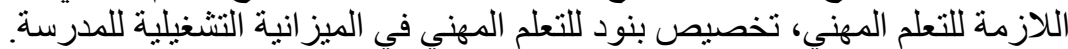

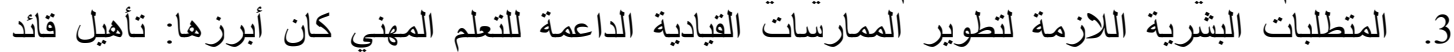

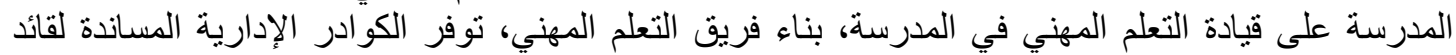
المدرسة، وجود منسقين للتعلم المهني على مستوى المدي لمدرسة.

ثانياً: توصيات الاراسة

في ضوء النتائج التي توصلت إلته إليها الدر اسة بمكن تقديم التوصيات الأتية:

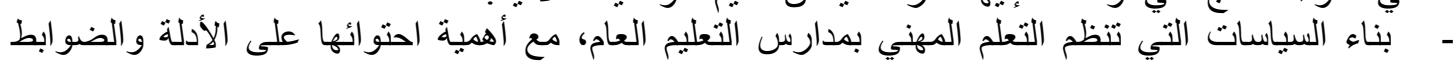
و آليات تطبيق نماذج التعلم بخطو ات و اضحة لجميع منسوبي المدرسة. 


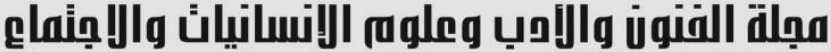

Journal of Arts, Literature, Humanities and Social Sciences www.jalhss.com

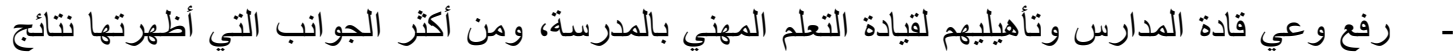

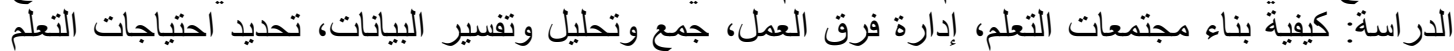

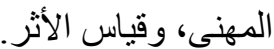

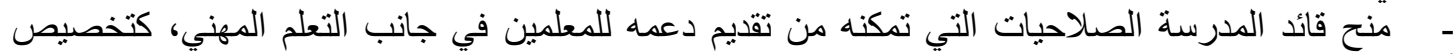

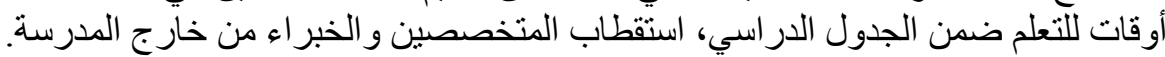

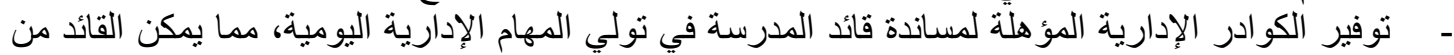

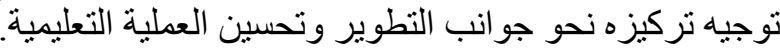

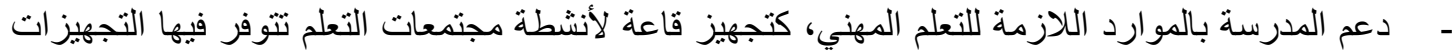
التقنية الأساسية، و إتاحة مصادر تعلم رقمية كالاشتر الك في منصات نعليمية.

1. الأحمري، شمسة. (2017م). المنظمة المتعلمة مدخل لتطوير الدور القيادي في المدارس. ط1، عمان: دار

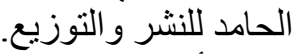

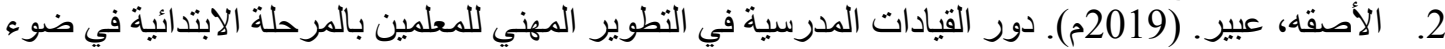

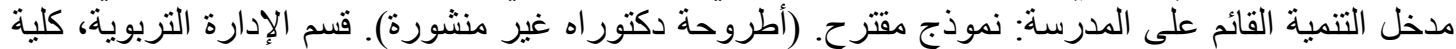
التربية، جامعة الملك سعود: الرياض. 3. البرنامج الوطني لنطوير المدارس. (1435هـ). نموذج تطوير المدارس. الإصدار الثاني، الرياض: شركة تطوير للخدمات التعليمية.

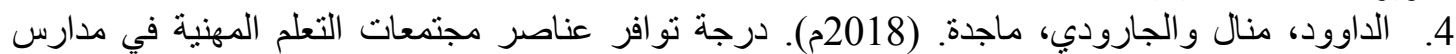

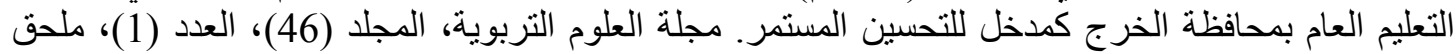

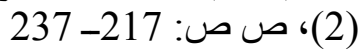
5. الرواحية، بدرية. (2014م). تصور مقترح لتفعيل الممارسات القيادية الداعمة لمجتمعات التعلم المهنية بمدارس التعليم الحكومية في سلطنة عمان. رسالة ماجستير، قسم الأصول والإدارة التربوية، جامعة السلة السلطان قابوس: سلطنة عمان. 6. سليمان، عماد. (2020م). الممارسات القيادية لمديري مدارس التعليم الأساسي بمصر. مجلة كلية التربية،

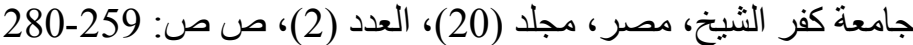

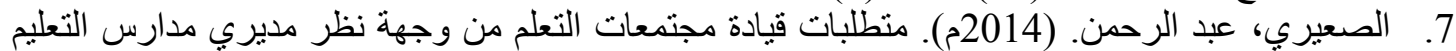

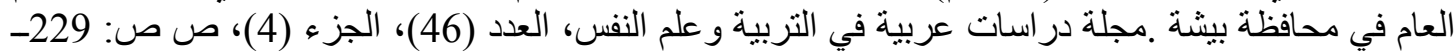

8. العساف، صالح. (24806). الدذخل إلى البحث في العلوم السلوكية. ط4، الرياض: العبيكان.

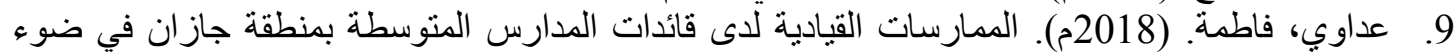

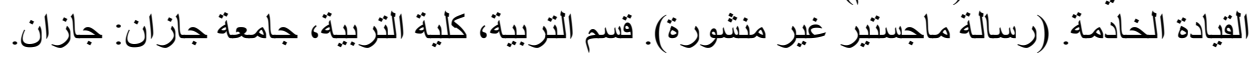

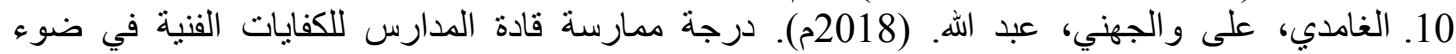

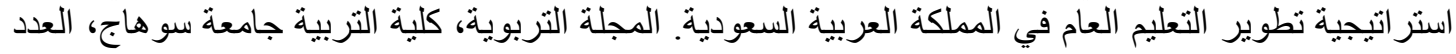

(51)، ص ص: 112-72

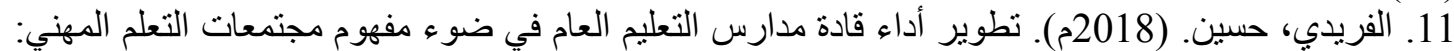

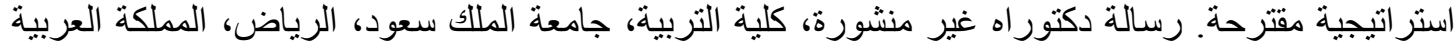
12. آل مقبل، محمد. (2015م). نظام المدرسة المتعلمة الداعم للوصول إلى مجتمع المعرفة: نموذج مقتر ح.

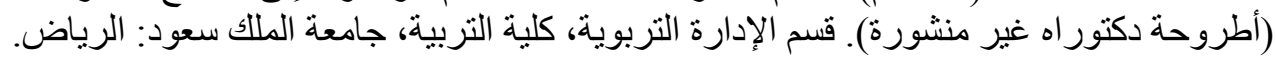

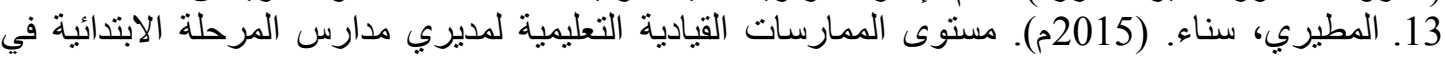

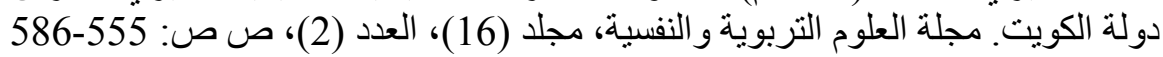




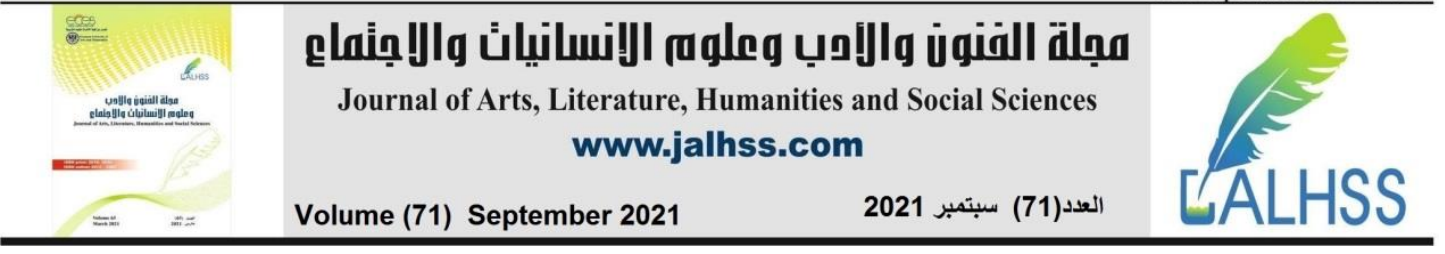

14. وزارة التعليم. (1440هـ). هيئة تقويم التعليم تعتمد معايير وطنية لمناهج التعليم العام. تاريخ الاسترجاع

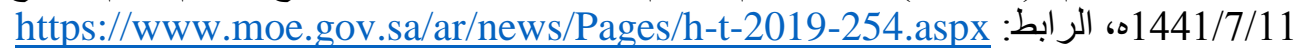

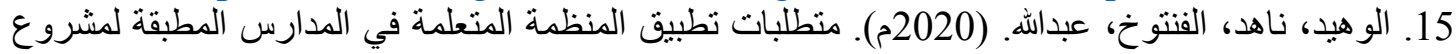

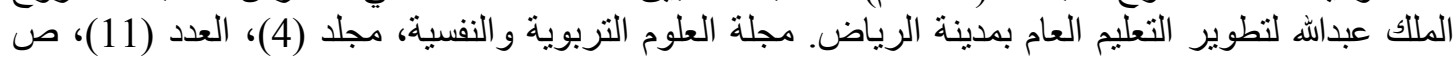
1. Australian Institute for Teaching and School Leadership (AITSL). (2014). Designing Professional Learning. Melbourne: Australia.

2. Dawson, C. (2002). Practical Research Methods: A user-friendly guide to mastering research techniques and projects. Oxford: How to Books Publication. 3. DuFour, R., Eaker, R. (1998). Professional Learning Communities at work: Best Practices for Enhancing Student Achievement. Bloomington: National Educational Service.

4. Erkens, C., Twadell, E. (2012). Leading by design: an action framework for PLC at Work leaders. Indiana: Solution Tree Press.

5. Hitt, D., Tucker, P. (2016). Systematic Review of Key Leader Practices Found to Influence Student Achievement: A Unified Framework. Review of Educational Research, 86(2), 531-569

6. Kouzes, J., Posner, B. (2012). The leadership challenge: how to make extraordinary things happen in organizations. 5th ed, San Francisco: Jossey-Bass publication.

7. Louis, K., Hord, S. \& Frank, V. (2017). Reach the highest standard in professional learning: Leadership. Thousand Oaks, CA: Corwin \& Learning Forward.

8. Leithwood, K. (2012). The Ontario Leadership Framework 2012: with a Discussion of the Research Foundations. Ontario: The Institute for Education Leadership.

9. Leithwood, K., Louis, K. (2012). Linking Leadership to Student Learning. San Francisco: Jossey-Bass publication.

10. Mendels, P. (2012). The Effective Principal. Journal of Staff Development, 33(1), 54-56.

11. Waterhouse, J, Moller, J. (2009). Shared Leadership. In MacBeath, J., Dempster, N. (Eds.), Connecting Leadership and Learning: Principles and Practice (pp.121-136). London and New York: Routledge. 